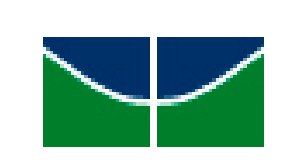

\author{
Universidade de Brasília \\ Faculdade UnB Planaltina (FUP) \\ Programa de Pós-Graduação em Gestão Pública \\ Mestrado Profissional em Gestão Pública
}

\title{
SENSIBILIDADE INTERCULTURAL DOS DIRETORES DE ESCOLAS PÚBLICAS NO BRASIL
}

\author{
Rayane de Oliveira Carvalho
}

Brasília-DF

2016 


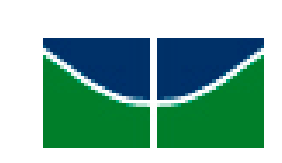

\author{
Universidade de Brasília \\ Faculdade UnB Planaltina (FUP) \\ Programa de Pós-Graduação em Gestão Pública \\ Mestrado Profissional em Gestão Pública
}

\title{
SENSIBILIDADE INTERCULTURAL DOS DIRETORES DE ESCOLAS PÚBLICAS NO BRASIL
}

Rayane de Oliveira Carvalho

Dissertação apresentada ao Programa de PósGraduação da Faculdade UnB Planaltina (FUP) no Curso de Mestrado Profissional em Gestão Pública como requisito parcial para obtenção do título de mestre em gestão pública.

Orientador: Prof. Dr. Luiz Honorato da Silva Júnior

\section{Brasília-DF}




\section{Agradecimento}

Agradeço a Deus, sem Ele nada disso seria possível.

À minha família pelo apoio incondicional.

Em especial, aos meus queridos pais por me concederem o belo fluxo da vida.

À minha querida irmã por estar sempre presente me apoiando.

À minha doce filha que me acompanhou desde o ventre.

Ao meu amado esposo, pelo apoio, compreensão e motivação.

Ao professor Luiz Honorato, meu orientador e docente, a quem agradeço, por despertar em mim o interesse pelo tema e a vontade de continuar.

A Valentin, que apresentou este tema tão relevante.

A todas as pessoas queridas do MEC e FNDE que me auxiliaram na construção deste trabalho. Aos colegas de trabalho que fizeram parte de toda a jornada e souberam me ajudar na hora certa. Aos amigos que conquistei neste período de aprendizado e crescimento pessoal, vocês tornaram tudo mais leve e divertido. 
Ficha catalográfica elaborada automaticamente, com os dados fornecidos pelo(a) autor(a)

ds

de Oliveira, Rayane

SENSIBILIDADE INTERCULTURAL DOS DIRETORES DE ESCOLAS PÚBLICAS NO BRASIL / Rayane de Oliveira; orientador Luiz Honorato da Silva Júnior. -Brasilia, 2017. $70 \mathrm{p}$.

Dissertação (Mestrado - Mestrado Profissional em Gestão Pública) -- Universidade de Brasilia, 2017.

1. Sensibilidade Intercultural. 2. Modelo de Regressão. 3. Educação Básica. I. da Silva Júnior, Luiz Honorato, orient. II. Título. 


\section{Rayane de Oliveira}

\section{SENSIBILIDADE INTERCULTURAL DOS DIRETORES DE ESCOLAS PÚBLICAS NO BRASIL}

Trabalho de Conclusão submetido ao Programa de Pós-Graduação no Curso de Mestrado Profissional em Gestão Pública da Universidade de Brasília como um dos requisitos para obtenção do título de Mestre em Gestão Pública.

Aprovado em 23 de janeiro de 2017.

BANCA EXAMINADORA

Professora Doutor Luiz Honorato da Silva Júnior - Presidente da Banca

Universidade de Brasília - UnB

Professor Doutor Valentin Santander - Membro Externo

Universidade de Brasília - UnB

Professora Doutor Mauro Del Grossi - Membro Interno

Universidade de Brasília - UnB 
Grande é apenas aquele que se sente igual aos outros, pois a maior grandeza que possuímos é aquilo que compartilhamos com todos os seres humanos. Quem sente essa grandeza dentro de si e a reconhece se sabe grande e, ao mesmo tempo, conectado a todos os outros seres humanos. Quando alguém reconhece tal grandeza dentro de si, também a reconhece em todos os outros seres humanos e sabe e sente ser igual a eles.

(Bert Hellinger) 


\section{Resumo}

Este trabalho tem por objetivo mensurar o grau de sensibilidade intercultural dos diretores de escolas públicas no Brasil e buscar evidências sobre quais características individuais, institucionais, socioeconômicos e localizacionais se relacionam com tal aspecto. A sensibilidade intercultural traduz aspectos comportamentais em situações de interação entre indivíduos de culturas diferentes. Ela é uma das competências importantes para que profissionais da educação possam desempenhar melhor seu trabalho pedagógico dentro do ambiente escolar. Para o objetivo deste trabalho foi proposto um Índice de Sensibilidade Intercultural - ISI e em seguida, foram feitas regressões econométricas em MQO com o objetivo de correlacionar tais características com o índice proposto. A partir dos resultados desses modelos foi proposto um perfil dos diretores de escola pública de educação básica em relação à sensibilidade intercultural. Com as evidencias obtidas pelo modelo, propôs-se a orientação de políticas públicas voltadas ao tema.

Palavras-chaves: Sensibilidade Intercultural; Modelo de Regressão; Educação Básica. 


\begin{abstract}
The objective of this study is to measure the degree of intercultural sensibility of public school principals in Brazil and and to search for evidence about which individual, institutional, socioeconomic and location characteristics relate to this aspect. Intercultural sensitivity translates behavioral aspects in situations of interaction between individuals of different cultures. It is one of the main competencies for education professionals and works best in their pedagogical work within the school environment. For the purpose of this study, it was proposed an Intercultural Sensitivity index-ISI, and then econometric regressions have been made in MQO aiming to correlate these characteristics with the proposed index. Based on the results of the models proposed in the profile of the principals of the public school of basic education in relation to intercultural sensibility. With the evidence obtained by the model, it has been proposed that the orientation of public policies aimed at the theme.
\end{abstract}

Key words : Intercultural Sensitivity; Regression Model; Basic education. 


\section{Lista de Figuras}

Figura 1 - Desenvolvimento da Sensibilidade Intercultural 21

Figura 2 - Representação da ligação entre necessidade de informação e dados 31

Figura 3 - Fluxo de e-mails aos Diretores de Escolas Públicas 35

Figura 4 - Modelo de reta de regressão linear .............................................................. 37

Figura 5 - Representação da Reta de Regressão ............................................................ 38

Figura 6 - Índice de Sensibilidade Intercultural médio por sexo na amostra ......................... 49

Figura 7 - Índice de Sensibilidade Intercultural médio por idade do indivíduo típico na amostra 50

Figura 8 - Índice de Sensibilidade Intercultural médio por Estado Civil na amostra ............... 51

Figura 9 - Índice de Sensibilidade Intercultural médio por Escolaridade na amostra ............. 51

Figura 10 - Índice de Sensibilidade Intercultural médio e a Renda dos diretores de escola ...... 52

Figura 11 - Índice de Sensibilidade Intercultural médio por grupos religiosos na amostra ...... 54 


\section{Lista de Tabelas}

Tabela 1 - Número de escolas de educação básica por dependência administrativa Brasil $2008 / 2014$ 34

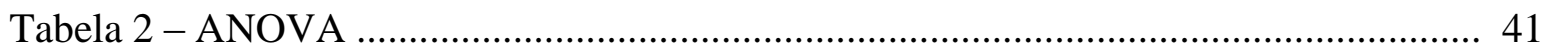

Tabela 3 - Estatísticas Descritivas do Grupo de Diretores de Escolas Públicas ............... 45

Tabela 4 - Resultados dos Modelos de Regressão MQO ............................................... 47 


\section{Lista de Siglas}

$\begin{array}{ll}\text { ANOVA } & \text { Análise de Variância } \\ \text { ISI } & \text { Índice de Sensibilidade Intercultural } \\ \text { SPSS } & \text { Statistical Package for the Social Sciences } \\ \text { SQR } & \text { Soma dos quadrados dos erros } \\ \text { SQReg } & \text { Soma dos quadrados da regressão } \\ \text { SQT } & \text { Soma dos quadrados totais }\end{array}$




\section{Lista de Símbolos}

$\begin{array}{ll}\sigma & \text { Sigma } \\ \varepsilon & \text { erro aleatório } \\ \sigma^{2} & \text { variância } \\ \mathrm{k} & \text { número de variáveis preditoras } \\ \beta 0 & \text { intercepto da reta no eixo da ordenada } \\ \beta \mathrm{k} & \text { inclinação da reta } \\ \mathrm{n} & \text { número de observações } \\ \mathrm{x} & \text { variável preditora } \\ \mathrm{y} & \text { preditando } \\ \mathrm{y}^{\wedge} & \text { valores estimados para y } \\ \mathrm{y}^{\wedge} 2 & \text { variância estimada } \\ \mathrm{H} 0 & \text { hipótese nula } \\ \mathrm{H} 1 & \text { hipótese alternativa } \\ \mathrm{F} 0 & \text { distribuição F-Snedecor } \\ \mathrm{t} 0 & \text { distribuição t-student } \\ R^{2} & \text { coeficiente de determinação } \\ \mathrm{R} & \text { coeficiente de regressão múltipla } \\ R_{a j}^{2} & \text { coeficiente de determinação ajustado }\end{array}$




\section{SUMÁRIO}

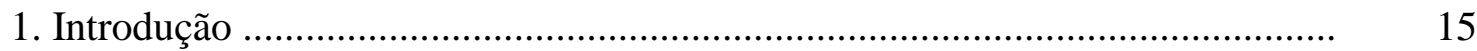

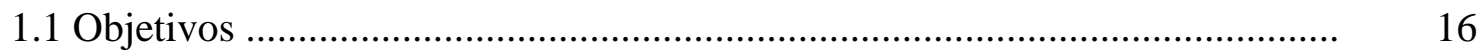

1.2 Justificativa e relevância do estudo ................................................................ 17

2. Revisão de literatura ............................................................................... 18

2.1. Conceituando Sensibilidade Intercultural e o DMIS ...................................... 18

2.2. Diversidade cultural, interculturalidade e multiculturalidade ........................ 22

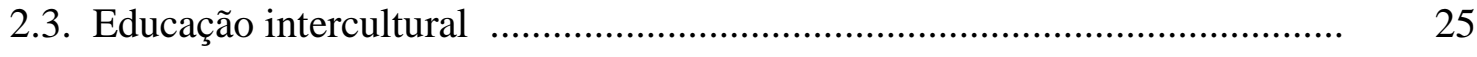

2.4. Migrações no Brasil ............................................................................. 28

3. Metodologia ……......................................................................... 30

3.1. Questionário ................................................................................... 31

3.1.1 Pré -Teste …………………………………....................................... 32

3.2 O Sistema LimeSurvey …………............................................................ 33

3.2.1 Levantamento de dados ........................................................................ 33

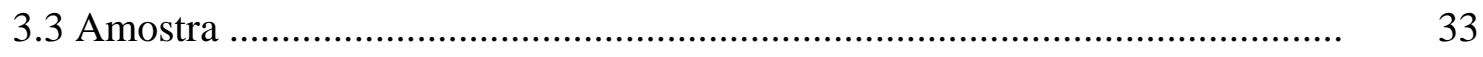

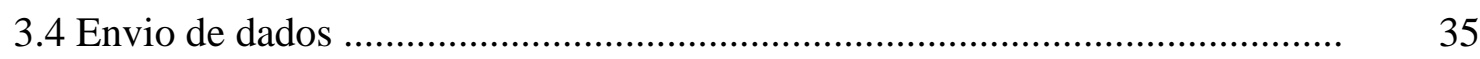

4. Índice de Sensibilidade Intercultural (ISI) ...................................................... 36

4.1 Modelo Econométrico ............................................................................. 36

4.1.1 Regressão Linear .................................................................................. 37

4.1.2 Método dos Mínimos Quadrados ................................................................. 38

4.1.3 Multicolinearidade .............................................................................. 40

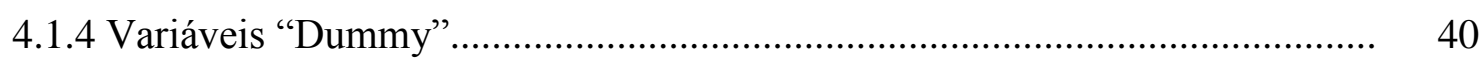

4.1.5 Teste de Hipóteses ............................................................................... 40

4.1.6 Coeficientes de Avaliação e Qualidade do Modelo............................................ 42

4.1.7 Testes de Significância .................................................................................. 43

5. Análise de Resultados .................................................................................

5.1. Resultados das Regressões ...................................................................... 48

6. Considerações Finais ............................................................................. 58

7. Referências bibliográficas ............................................................................. 60

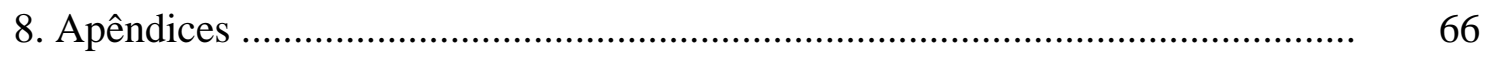





\section{Introdução}

Em um país com tamanha extensão territorial e grande miscigenação, onde se sabe haver sérios problemas de preconceito contra determinados grupos sociais, como os diretores de escolas tratam questões de interculturalidade em seu ambiente de trabalho? Como é sua relação com culturas distintas, em um país no qual a migração entre regiões é significativa, e a diversidade cultural é ampla?

Tais questões têm sido amplamente debatidas mais recentemente sob a alcunha de sensibilidade intercultural. Bennet (1993) conceitua sensibilidade intercultural através de um modelo de Desenvolvimento de Sensibilidade Intercultural (DMIS). Neste sentido, a sensibilidade intercultural passa por dois estágios: o etnocentrismo e o etnorelativismo. Ainda segundo o referido autor, na fase etnocentrista, depara-se com comportamentos de negação, defesa e minimização frente a culturas distintas. Na etapa etnorelativistas, defronta-se com aceitação, adaptação e integração. Para Bennet, quanto mais sofisticadas forem as experiências pessoais com diferentes culturas, maiores serão as competências interculturais do indivíduo.

Para Arne Gillert (2006), desenvolver uma sensibilidade intercultural significa, na sua essência, aprender a reconhecer e gerir as diferenças fundamentais que dizem respeito à percepção do mundo pelas culturas.

A sensibilidade intercultural é um tema recentemente discutido na academia. Ela é uma das competências necessárias para que profissionais da educação possam desempenhar melhor seu trabalho pedagógico dentro do ambiente escolar.

Segundo Bennett (2004), desenvolver a sensibilidade intercultural exige que seja dada atenção à experiência subjetiva do aprendiz. Ainda diz que a chave de tal sensibilidade e de habilidades relacionadas com esta na comunicação intercultural é a forma como os aprendizes percebem diferenças culturais.

De acordo com Barden, Shannonhouse e Mobley (2015), sensibilidade no trabalho com pessoas de culturas diversas é utilizada como argumento para aumentar a compreensão de como as diferenças culturais se tornam mais complexas. Sensibilidade intercultural é considerada a atitude precursora da competência cultural, definida por Hammer, Bennett e Wiseman (2003) como "atingir a capacidade de interpretar e experimentar as diferenças culturais, de formas mais complexas"(p.421). 
Existe extensa literatura sobre este assunto na academia europeia, entretanto poucos são os estudiosos brasileiros que tratam do assunto. Grande parte dos autores brasileiros evidenciou a educação estética e a educação intercultural, não dando destaque à sensibilidade intercultural. Fato que torna o objeto de pesquisa contemporâneo para a academia nacional. Ademais, o trabalho traz a proposta de utilização de modelo de regressão para a análise quantitativa dos dados obtidos através de questionário feito aos diretores de escolas públicas de educação básica.

Os resultados obtidos poderão ser de grande relevância social e um importante instrumento de decisão para a gestão e formulação de políticas. Para a sociedade, revela como se dá a relação dos diretores com culturas distintas. Para a gestão e formulação de políticas, caso a relação seja desfavorável, traz a possibilidade de planejamento e implementação de projetos orientados a um melhor convívio entre a comunidade pedagógica e as diversas culturas existentes no país.

\subsection{Objetivos}

O objetivo geral deste projeto é mensurar o grau de sensibilidade intercultural dos diretores de escolas públicas no Brasil e buscar evidências sobre quais características individuais, institucionais, socioeconômicos e localizacionais influenciam nesse grau de sensibilidade intercultural.

Os objetivos específicos desenvolvidos para tanto são:

- $\quad$ Construir e validar um índice para medir o grau de sensibilidade intercultural.

- Mensurar o grau de sensibilidade intercultural entre os diretores de escola pública de educação básica.

- Conhecer o perfil dos diretores de escola pública de educação básica em relação à sensibilidade intercultural.

- $\quad$ Analisar a relação entre o índice de sensibilidade intercultural e o perfil dos diretores.

- A partir dos resultados encontrados, orientar políticas públicas. 


\subsection{Justificativa e relevância do estudo}

A diversidade cultural é um desafio para a sociedade moderna, exige flexibilidade para aceitar o diferente e força para conservar as raízes históricas - o equilíbrio entre esses fatores é complexo.

A sensibilidade intercultural é relevante para a pesquisa acadêmica, pois se sustenta na importância do exercício de uma docência comprometida com a formação humana.

Além de reorientar o pesquisador para desvendar a interculturalidade de forma mais abrangente, mitigando horizontes reducionistas da realidade, a pesquisa tem relevância para a para a Academia, para a Administração Pública e, sobretudo, para a sociedade.

Para a Academia o estudo é relevante por trazer contribuições à compreensão do grau de sensibilidade dos diretores através de uma nova ferramenta analítica para estudar esse tema: os métodos de regressão.

Para a Administração Pública, o estudo é pertinente por subsidiar a formulação e implementação de políticas públicas, na área de educação, voltadas para a interculturalidade. Subsidiar processos de formação continuada voltada a inclusão, educação estética e formação

humana. Conforme Fleuri: “ [...] buscando elucidar estratégias teórico-metodológicas para a formação de educadores(as) na perspectiva da educação intercultural como uma das possibilidades de ruptura das mediações monoculturais que perpassam as escolas, a formação e as ações educativas de educadores(as) no Brasil” .

O estudo é também relevante para o conjunto da sociedade, na condição de destinatária final das ações do Estado, pelas consequências práticas que poderão advir do aprofundamento da discussão sobre a sensibilidade intercultural dos diretores das escolas públicas.

Trata-se de um objeto de pesquisa relativamente novo e com (relativamente) pouca contribuição. Assim, este trabalho de pesquisa pretende contribuir mensurando a sensibilidade intercultural dos diretores de escolas públicas da educação básica e estimando quais características estariam mais relacionadas com a sensibilidade destes profissionais da educação. 


\section{Revisão de Literatura}

Este Capítulo é destinado a apresentar o corpo teórico sobre o qual será edificada a pesquisa. De início serão tratadas definições de Sensibilidade Intercultural e o DMIS. Em seguida, serão abordadas as diferentes perspectivas utilizadas para a compreensão dos conceitos de diversidade cultural, interculturalidade e multiculturalidade. A partir daí, será dada ênfase à educação intercultural. Por fim tratar-se-á de migrações no Brasil.

Esta seção pretende apresentar o atual estado da arte sobre o tema trazendo à luz os principais trabalhos já publicados relacionados a esta pesquisa.

\subsection{Conceituando sensibilidade intercultural e o DMIS}

Hammer, Bennett e Wiseman (2003) definem sensibilidade intercultural como a habilidade de discriminar e experimentar diferenças culturais relevantes. Por outro lado, o termo competência intercultural se refere à capacidade de pensar e agir de maneira interculturalmente adequada. Os referidos autores argumentam ainda que uma maior sensibilidade intercultural é associada a um maior potencial para o exercício de competências interculturais.

Adicionalmente, revelam que pesquisas de outros autores, como Gardenswartz \& Rowe (1993), sobre relações interculturais domésticas (contato através de formas de etnia, gênero, idade, orientação sexual, etc) tem encontrado um papel-chave para competência intercultural.

Competência intercultural é vista como central no aumento da compreensão e melhoria das relações entre culturas (Bennett, 1993a, b; Hammer, 1999b).

De acordo com Hammer, Bennett e Wiseman (2003):

O modelo do desenvolvimento da sensibilidade Intercultural (DMIS) foi criado por Bennett (1986, 1993b) como uma explicação de como as pessoas interpretam a diferença cultural. Usando uma abordagem de teoria fundamentada (Glaser e Strauss, 1967; Strauss e Corbin, 1990), Bennett aplicou conceitos de construtivismo cibernético (Von Foerster, 1984; Brown, 1972; Maturana e Varela, 1987) às suas observações de adaptação intercultural e identificou seis orientações que as pessoas parecem se mover através de sua aquisição da competência intercultural. O pressuposto subjacente do modelo é que à medida 
que a experiência da diferença cultural torna-se mais complexa e sofisticada, aumenta a competência do indivíduo em potencial nas relações interculturais. $[\ldots]$

O conjunto de distinções que é apropriado para uma cultura em particular é referido como uma visão cultural. Indivíduos receberam uma socialização largamente monocultural normalmente têm acesso apenas a sua própria visão de mundo cultural, de modo que eles são incapazes de interpretar (e, portanto, são incapazes de experimentar) a diferença entre sua própria percepção e de pessoas que são culturalmente diferentes. O cerne do desenvolvimento da sensibilidade intercultural é atingir a capacidade de interpretar (e, portanto, de experimentar) a diferença cultural de formas mais complexas.(Hammer et. al, p. 423)

Segundo Chen e Starosta (1997), a sensibilidade intercultural é uma das habilidades mais importantes que nos ajudam a viver com sucesso em uma sociedade culturalmente diversificada.

Para Bennett (1998) a sensibilidade cultural é "um processo de crescimento pessoal do indivíduo, no seu modo de perceber e de avaliar as diferenças culturais. Nesse processo, o indivíduo alcança níveis superiores em sua capacidade de reconhecer, de se adaptar e de aceitar as diferenças culturais.” Bennett (1986) postulou um modelo de sensibilidade intercultural, o modelo do desenvolvimento da sensibilidade intercultural (DMIS) que é baseado em conceitos de psicologia cognitiva e construtivismo e opera no pressuposto de que os indivíduos seguem um caminho previsível, quando ganham experiência com diferentes culturas. (Hammer et al., 2003).

Os textos de Hammer et. al (2003) e Bennett e Bennett (2004), entre outros autores, conceituam os estágios do modelo de sensibilidade intercultural (DMIS). As três primeiras orientações do DMIS são conceituadas como mais etnocêntricas, o que significa que a própria cultura é experimentada como central para a realidade de alguma forma. O primeiro estágio é a Negação, onde o sujeito percebe sua cultura como a única real, recusando-se a perceber diferenças culturais. Numa forma mais extrema de negação, o povo de sua própria cultura pode ser percebido como o único " seres humanos 'reais' e outras pessoas são vistas como formas mais simples no ambiente a ser tolerado, explorado, ou eliminados, conforme necessário. Bennett sugere que a negação da diferença cultural é a condição padrão típica de socialização primária, monocultural.

No estágio Defesa, a própria cultura é tida como a única que é viável de fato e as outras são denegridas. O mundo está organizado em " nós " e " eles ", em que a própria cultura é 
superior e outras culturas são inferiores. Pessoas de culturas dominantes são propensas a experimentar o estágio Defesa como um ataque a seus valores (muitas vezes percebida pelos outros como privilégios). Pessoas de culturas não-dominantes são mais propensos a experimentar o estágio Defesa como descoberta e solidificação de uma identidade cultural separada em contraste com o grupo dominante (cf., Banks, 1988; Parham, 1989).

No estágio Minimização, elementos da própria cultura são tidos como universais, mas as diferenças são, agora, reconhecidas. Há, porém, minimização da sua significância - semelhanças com a própria cultura são valorizadas e diferenças são banalizadas. As pessoas no estágio de Minimização esperam por semelhanças, e elas podem se tornar insistentes sobre como corrigir o comportamento dos outros, para corresponder às suas expectativas. Particularmente para as pessoas de culturas dominantes, minimização tende a mascarar o reconhecimento de sua própria cultura (etnia) e o privilégio institucional que proporciona a seus membros.

As três últimas orientações do DMIS são definidas como etnorelativistas, significando que a própria cultura é experimentada no contexto de outras culturas. Aceitação da diferença cultural é o estágio em que a própria cultura é experimentada como apenas uma de uma série de igualmente complexas visões de mundo e onde o outro que é percebido como diferente é tido como igualmente humano. O principal problema a ser resolvido nesta perspectiva considerá a ' relatividade de valor '. Para aceitar a relatividade de valores para o contexto cultural (e, portanto, para atingir o potencial de experimentar o mundo organizado por valores diferentes), as pessoas precisam descobrir uma maneira de manter o compromisso ético perante tal relatividade (Perry, 1970).

Na Adaptação, a experiência de outra cultura produz a percepção e o comportamento apropriados para essa cultura. A visão de mundo é expandida para incluir construções relevantes de outras visões de mundo cultural. Há um processo de acumulação, onde novos comportamentos são aprendidos e unidos aos comportamentos pessoais. Há também o desenvolvimento de empatia, onde se compreende o outro a partir da perspectiva desse.

No último estágio, chamado de Integração, o sujeito consegue movimentar-se entre diferentes visões de mundo, que coexistem em si. Bennett (1993a) descreve que a integração não é necessariamente melhor do que a adaptação em situações que exigem competência intercultural, mas é descritivo de um número crescente de pessoas, incluindo muitos membros de culturas nãodominantes, expatriados de longo prazo, e nômades globais . 
A figura 1 descreve os seis estágios do modelo de sensibilidade intercultural (DMIS). As três primeiras orientações são conceituadas como mais etnocêntricas e as três ultimas como etnorelativistas.

Figura 1 - Desenvolvimento da Sensibilidade Intercultural

$\stackrel{\text { Desenvolvimento da Sensibilidade Intercultural }}{\text { Experimentação de Diferenças }}$

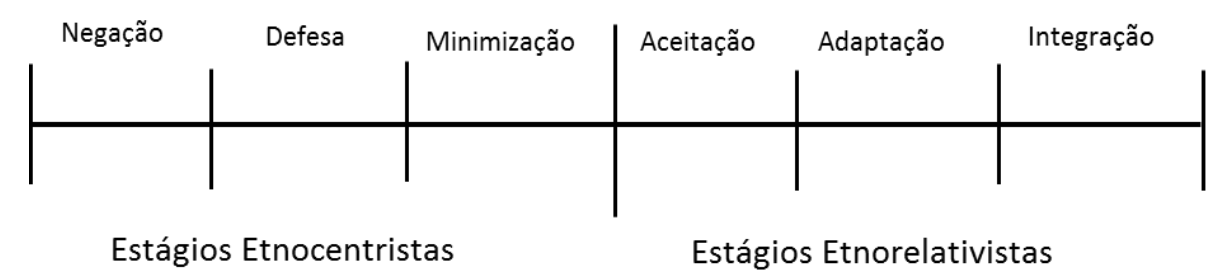

Fonte: Bennett, M. (1986).

A figura é explana o contínuo DMIS que se estende desde o etnocentrismo, a experiência da própria cultura como "central à realidade," ao etnorelativismo, a experiência da própria e de outras culturas como "em relação ao contexto." O Movimento do desenvolvimento é de sentido único, permanente e aplicável a qualquer coisa definida diferença cultural. Embora possa haver "retiros" de algumas posições. Maior ou menor familiaridade com culturas particulares não alteram o seu nível de sensibilidade, entretanto ela afeta a amplitude da competência que alguém pode se auto promulgar (BENNETT, 2004).

De acordo com Hammer et. al (2003), as orientações mais etnocêntricas, em geral, podem ser vistas como maneiras de evitar a diferença cultural, negando sua existência, elevando as defesas contra ela ou minimizando a sua importância. As visões de mundo mais etnorelativas são formas de buscar a diferença cultural, aceitando a sua importância, adaptando-se a perspectiva para levar isso em conta ou integrando o conceito em uma definição de identidade.

Segundo Bennett (2004), uma suposição feita pelo DMIS é que as pessoas podem ser mais ou menos "sensíveis" para a diferença cultural. Este conceito baseia-se na ideia construtivista de complexidade cognitiva (Delia, Crockett, e Gonyea, 1970; Goertzel,n.d.; Loevinger, 1970, Loevinger \& Wessler, 1979). 
Bennett (1986) afirma que desenvolver a sensibilidade intercultural exige atenção a experiência subjetiva do aprendiz. O autor explana que a chave para tal sensibilidade e habilidades relacionadas à comunicação intercultural é a maneira como a diferença cultural é interpretada. Bennett (1986) sugere que os estágios contínuos de crescimento pessoal permitem o diagnóstico do nível de sensibilidade de indivíduos e de grupos. O desenvolvimento contínuo move-se do etnocentrismo ao etnorelativismo. Os estágios de desenvolvimento são tipicamente ilustrados por declarações e comportamentos característicos que indicam o nível de sensibilidade.

O modelo de Bennett de sensibilidade intercultural requer não apenas a mudança gradual de afeto e cognição, mas também a capacidade comportamental para alcançar o estado de competência de comunicação intercultural. (Chen e Starosta, 1997).

De acordo com Chen e Starosta (1997):

Em primeiro lugar, embora a sensibilidade intercultural esteja relacionada com os aspectos cognitivos, afetivos e comportamentais em uma situação de interação, ela trata principalmente do nosso lado afetivo. Preocupa-se com a emoção em segundo lugar, a consciência intercultural (cognitiva) é a base da sensibilidade intercultural (afetivo) que, por sua vez, conduzirá à competência intercultural (comportamental). Em outras palavras, o três são conceitos estreitamente relacionados mas separados. Assim, a sensibilidade intercultural pode ser conceituada como "a capacidade de um indivíduo desenvolver uma emoção positiva para a compreensão e apreciação das diferenças culturais que promovem um comportamento adequado e eficaz na comunicação intercultural. Esta definição mostra que a sensibilidade intercultural é um conceito dinâmico. Revela que as pessoas interculturalmente sensiveis devem ter o desejo de se motivar para compreender, apreciar e aceitar as diferenças entre culturas, $e$ produzir um resultado positivo nas interações interculturais.

\subsection{Diversidade cultural, interculturalidade e multiculturalidade}

A cultura faz parte da totalidade de uma determinada sociedade, nação ou povo. Essa totalidade é tudo o que configura o viver coletivo. São os costumes, os hábitos, a maneira de pensar, agir e sentir, as tradições, as técnicas utilizadas que levam ao desenvolvimento e a interação do homem com a natureza. (SEED-PR, 2006). 
Em um mundo globalizado, como o de hoje, a problemática da diversidade cultural e da interculturalidade torna-se cada vez mais atual. Os intensos fluxos migratórios e a elevada velocidade de troca de informações através da rede mundial de computadores trazem a luz a multiculturalidade em expansão.

Fleuri (1999) adota a seguinte definição:

Já a relação intercultural indica uma situação em que pessoas de culturas diferentes interagem, ou uma atividade que requer tal interação. A ênfase na relação intencional entre sujeitos de diferentes culturas constitui o traço característico da relação intercultural.

Beltrán (2002) adota uma definição mais específica para o termo, faz um contraste entre intracultural e intercultural. A diversidade cultural, segundo ele, pode ser observada em dois aspectos. Primeiro, a diversidade intracultural, as culturas não são homogêneas de um ponto de vista interno, cada uma está constituída por diferentes segmentos e grupos sociais com identidades e características as quais se articulam por meio de um processo de ajuste, adaptação e negociação, a isto se chama diversidade intracultural. Em segundo lugar, as culturas tendem a se considerar homogêneas e a desfocar a diversidade interior quando se compara ou contrasta com outras culturas diferentes, a isto se chama diversidade intercultural. O conceito de diversidade cultural é uma tautologia, pois o que define a cultura, singular e plural, é justamente a diversidade.

Ainda segundo o autor, o estabelecimento , relativamente recente, de Estados-nação no mundo ocidental, foi baseado em um projeto que envolve a remoção e exclusão das diferenças culturais tradicionais no interior, a padronização e homogeneização de comportamentos e a imposição de uma série de ideias consideradas universais ou melhor nacionais. Beltrán ainda diz:

Numa época em que a cultura é cada vez mais sem raízes, com o aumento constante do volume e da velocidade de transmissão da informação $e$ disseminação descontrolada dos traços culturais, deve-se reconsiderar as supostas áreas culturais distintas.

Bartolomé e Cabrera (2003) acrescentam que o desafio da sociedade ocidental atual é lidar com a diversidade cultural e com o reconhecimento de identidades distintas no espaço coletivo , muitas vezes referido como o desafio do "multiculturalismo". 
Alguns autores fazem distinção entre multiculturalidade e interculturalidade:

- Uma perspectiva multicultural limita-se a considerar a coabitação das diferenças culturais como um processo histórico natural, espontâneo, do qual se pode tomar consciência para se adaptar a ele. Pode- se, ao invés, falar de interculturalidade quando consideramos não apenas o processo histórico de coexistência entre as diferentes culturas, mas também a proposta de mudança e de projetualidade (Nanni, 1998, p. 30).

- Na perspectiva multicultural, entende- se, de modo geral, as culturas diferentes como objetos de estudo, como matéria a ser aprendida. Ao contrário, na perspectiva intercultural os educadores e educandos não reduzem a outra cultura a um objeto de estudo a mais, mas a consideram como um modo próprio de um grupo social ver e interagir com a realidade. A relação entre culturas diferentes, entendidas como contextos complexos, produz confrontos entre visões de mundos diferentes. (Fleuri, 1999)

Tanto a globalização e a mobilidade das populações, como a urbanização, aumentaram sem precedentes os contatos entre as culturas e a coabitação entre diferentes grupos étnicoculturais e modos de vida contribuindo, assim, para a multi/interculturalidade das sociedades, particularmente das cidades, para a interdependência social e econômica, vindo colocar sérios desafios à gestão da diversidade cultural, à comunicação intercultural e à coabitação das várias culturas.(LAVALLEE; OUELLET; LAROSE, 1991; LABAT \& VERMES, 1994; WIEVIORKA, 1996).

A Organização das Nações Unidas para a Educação, a Ciência e a Cultura (UNESCO, 2001, p. 23) destaca na Declaração Universal sobre a Diversidade Cultural, artigo 3: "[...] uma das fontes de desenvolvimento, entendido não só como crescimento econômico, mas também como meio de acesso a uma existência intelectual, afetiva, moral e espiritual satisfatória."

O principal objetivo da interculturalidade é a coexistência e a interação de indivíduos e grupos de diversas culturas e identidades no mesmo espaço ou formação social (Beltran, 2002).

Alguns autores pontuam diferentes objetivos da interculturalidade: 
- a comunicação, um horizonte de diálogo e negociação (Beltran, 2002; Moreno, 1999);

- o conhecimento, a compreensão e o respeito pela sua própria cultura e a dos outros, em que a partir do conhecimento e respeito por si próprio, se constrói a capacidade de conhecimento e respeito da diferença (Zabalza, 1992), em que a compreensão de outras culturas é essencial para compreender a si mesmo (Cortina, 1999) e onde a compreensão do outros, sem impor nossos valores nem nos identificarmos necessariamente com eles é importante (Beltran, 2002);

- A interculturalidade é uma proposta de interpretação da vida social que enfatiza o respeito e o direito à diferença e que denuncia visões essencialistas, que em nome da cultura justifica a xenofobia, o racismo, a marginalização e a exclusão social (Beltran, 2002);

- A tolerância é não só aceitar passivamente os direitos de outros grupos culturais, mas também implica um reconhecimento ativo e abrangente dessas culturas (Sabariego, 2002);

- A abordagem intercultural coloca mais ênfase nas relações do que nas diferenças entre as culturas, que entendida de forma dinâmica influenciam umas as outras por meio dessas relações (Bartolomé e Cabrera , 2003). É importante ter a visão de que é muito mais o que nos une do que o que nos divide em diferentes culturas (Bartolomé et al, 1999) e que cada cultura é uma realidade multicultural , assim como cada um de nós é , de fato, multicultural ( Cortina , 1999);

- A diversidade cultural, o diálogo entre diferentes tradições culturais, a possibilidade de deixar o próprio nicho cultural e enriquecer-se com as contribuições dos outros e com o contraste crítico entre os diferentes pontos de vista, entre diferentes perspectivas, tem sido altamente apreciado desde o enfoco intercultural (Bartolomé, 2004).

\subsection{Educação intercultural}

A sensibilidade intercultural aplicada ao ambiente escolar proporciona a educação intercultural. Esta define um enfoque, procedimento, processo dinâmico de natureza social, em que os participantes são positivamente impulsionados a ser conscientes de sua interdependência e 
é, também, uma filosofia, política e pensamento que garanta tal enfoque (VELASCO, 2004). Ela é "estar com, viver com, conviver"; e é definida como uma "pedagogia do ouvir" (FALTERI, 1998).

O relatório Mundial da UNESCO - Investir na diversidade cultural e no diálogo intercultural pondera que:

Em sociedades multiculturais cada vez mais complexas, a educação deve auxiliarnos a adquirir as competências interculturais que nos permitam conviver com as nossas diferenças culturais e não apesar delas. Os quatro princípios de uma educação de qualidade definidos no Relatório da Comissão Mundial sobre Educação para o Século XXI (aprender a ser, aprender a conhecer, aprender a fazer e aprender a viver em conjunto) somente podem aplicar-se com êxito se a diversidade cultural for seu elemento central. (Relatório Mundial da UNESCO Investir na diversidade cultural e no diálogo intercultural - Resumo - p.15-16).

Segundo Fleuri(1998), educação, docência e sensibilidade são temas que se entrelaçam e se entretecem dando-se a ver em múltiplos e variados espaços. A escola é um deles. E ela também é, por excelência, o lugar da docência e da possibilidade de fazer acontecer uma educação de abordagem intercultural. O horizonte dessa abordagem é constituído a partir da criação de contextos educativos que oportunizem a integração e a interação criativa, crítica e cooperativa tanto entre os diferentes sujeitos, quanto seus contextos sociais, econômico-políticos e culturais.

No contexto das lutas sociais contra os processos crescentes de exclusão econômicopolítica, a educação intercultural propõe, em nível das práticas educacionais, o desenvolvimento de estratégias que promovam a construção de identidades particulares e o reconhecimento das diferenças, ao mesmo tempo que sustentem sua inter-relação crítica e solidária (Scherer-Warren, 1998, p. 31-32).

Nanni a define como um processo multidimensional, de interação entre sujeitos de identidades culturais diferentes. Estes, através do encontro intercultural, vivem uma experiência profunda e complexa de conflito/ acolhimento. É uma oportunidade de crescimento da cultura pessoal de cada um, na perspectiva de mudar estruturas e relações que impedem a construção de 
uma nova convivência civil. A educação intercultural promove inclusive a mudança do sistema escolar: defende a igualdade de oportunidades educacionais para todos, requer a formação dos educadores, estimula a reelaboração dos livros didáticos, assim como a adoção de técnicas e de instrumentos multimediais (Nanni, 1998, p. 50).

Segundo Darcy Ribeiro (1995), a sociedade e a cultura brasileiras são conformadas como variantes da versão lusitana da tradição civilizatória europeia ocidental, diferenciadas por coloridos herdados dos índios americanos e dos negros africanos. O Brasil emerge, assim, como um renovo mutante, remarcado de características próprias, mas atado genesicamente à matriz portuguesa, cujas potencialidades insuspeitadas de ser e de crescer só aqui se realizariam plenamente.

O autor complementa que:

A confluência de tantas e tão variadas matrizes formadoras
poderia ter resultado numa sociedade multiétnica, dilacerada pela
oposição de componentes diferenciados e imiscíveis. Ocorreu justamente
o contrário, uma vez que, apesar de sobreviverem na fisionomia
somática e no espírito dos brasileiros os signos de sua múltipla
ancestralidade, não se diferenciaram em antagônicas minorias raciais,
culturais ou regionais, vinculadas a lealdades étnicas próprias e
disputantes de autonomia frente à nação. As únicas exceções são
algumas microetnias tribais que sobreviveram como ilhas, cercadas pela
população brasileira. Ou que, vivendo' para além das fronteiras da
civilização, conservam sua identidade étnica. São tão pequenas, porém,
que qualquer que seja seu destino, já não podem afetar à macroetnia em
que estão contidas.

Carneiro (1994) em seu trabalho diz que a partir de Silvio Romero a cultura brasileira passa a ser compreendida como o resultado da mistura das raças, entendidas não apenas no plano biológico como também no plano espiritual. Na procura de respostas sobre nossa brasilidade, Romero encontrou no mestiço a sua maior afirmação. "Pouco adianta discutir se isto é um bem ou um mal; é um fato e basta." (Romero, 1953, p. 133). Ou seja, o autor reitera que a sociedade e 
cultura brasileiras são resultado da mistura de diversas raças. O que gera enorme diversidade cultura na nossa extensão territorial.

\subsection{Migrações no Brasil}

As migrações são de grande relevância para a sensibilidade intercultural. Elas permitem que o indivíduo tenha contato com diferentes culturas, ou porque migrou, ou porque seu território recebe algum migrante. Nesse contexto, faz se necessário contextualizar as migrações no Brasil.

Segundo Vainer (2005), o migrante é considerado como um indivíduo dotado de racionalidade econômica na decisão de migrar e, portanto, capaz de desenhar os seus caminhos pelo território de uma maneira adequada às necessidades do mercado de trabalho. Como se cada migrante fosse um "empresário de si mesmo" a procurando a localização ótima para o seu “capital humano".

Segundo os autores Todaro e Lewis, é observado nos países em desenvolvimento, uma oferta ilimitada de força de trabalho, ou, em outras palavras, economias onde prevalece uma população numerosa com um grande crescimento vegetativo, face ao capital e aos recursos naturais disponíveis. Dadas as diferenças estruturais entre os setores rural e urbano da economia, é de importância decisiva a transferência de mão de obra entre os dois setores.

As migrações foram determinantes na história brasileira recente, contribuindo decisivamente para as particularidades do seu processo de urbanização. Este processo só se acelerou e assumiu uma dimensão realmente estrutural na segunda metade do século passado. Somente na década de sessenta é que a população urbana superou a rural. A velocidade do processo de urbanização, muito superior à dos países capitalistas mais avançados, foi a grande novidade do caso brasileiro. (Brito, 2009)

Na maior parte da segunda metade do século passado, o mais importante fluxo regional de migrantes no Brasil envolveu as interações entre o Nordeste, pobre, e São Paulo, estado mais industrializado e rico do país, configurando um padrão espacial de sentido norte-sul. De fato, a industrialização e a urbanização acelerada iniciadas nos anos 1950 ocorreram quando a mortalidade havia iniciado sua queda e a taxa de crescimento populacional foi a maior da história brasileira, de 3,0\% ao ano. As áreas menos desenvolvidas e de alta fecundidade fomentaram enormes reservatórios de mão de obra (Vainer e Brito, 2001) 
Vainer e Brito, na procura de pontos de referência que podem ajudar a identificar os principais movimentos e grandes tendências que caracterizam a nossa história migratória, pontuam que é possível identificar três grandes períodos:

- 1888 - 1930, período de constituição de um mercado de trabalho livre, caracterizada pela predominância da imigração internacional;

- 1930 - 1980, período dominado pelo processo de industrialização e pela ocupação acelerada da fronteira agrícola, durante o qual agrícola modernização e o processo correlato de proletarização maciça da população rural vai gerar migração interna de fronteiras e cidades, estabelecendo um processo de urbanização explosiva (e, até mesmo, metropolização) e a configuração de um mercado nacional de força de trabalho;

- 1980, período cujas principais tendências ainda serão definidas, mas que parece ser dominado pela queda das taxas de crescimento econômico, por uma saturação relativa da capacidade de absorção nas fronteiras e metrópoles, por um processo de circulação generalizada de populações migrantes, por uma absorção seletiva e excludente em mercados de trabalho e pela introdução significativa da migração internacional .

Diante da demarcação dos períodos citados, Vainer e Brito esclarecem que é necessário ter em mente que os grandes períodos aqui demarcados devem ser entendidos como, aproximações grosseiras e iniciais permitindo a identificação das grandes tendências e dinâmica migratória dominante. Estamos lidando aqui com um processo histórico complexo que não pode ser escondidos dentro de intervalos marcados por tendências unívocas e lineares. Muito pelo contrário, longe de seguir por caminhos definidos por tendências estáveis, a história é feita de oscilações (em seu conjunto) resultante da coexistência, às vezes harmoniosa e em outras vezes conflitantes, de múltiplas tendências, da sobrevivência do passado e do prenúncio de realidades mal emergentes.

As fases iniciais do alto crescimento natural e das migrações rural-urbanas foram seguidas pela diminuição desse tipo de fluxo, concomitantemente ao aumento dos movimentos urbanourbano. Estas fases coincidem com os estágios iniciais e das sociedades avançadas, postulados por Zelinsky (1971). 


\section{Metodologia}

Neste capítulo serão apresentadas as características da pesquisa a ser realizada determinando os instrumentos a serem utilizados e suas delimitações.

Esta pesquisa tem por característica ser aplicada, pois visa a criação de um instrumento de uso prático e é também quali-quantitativa, por tratar de valores pertinentes ao resultado de um levantamento de dados oriundo de opiniões e valores individuais dos pesquisados além da realização de pesquisa bibliográfica, junto ao banco de dados relacionado neste trabalho (YIN, 2005).

Para este estudo utilizou-se banco de dados fornecido pelo Ministério da Educação - MEC através da Lei de Acesso à Informação - LAI. Foi solicitado pelo gestor, que detinha a base de dados, que fosse efetuado cadastro no sistema E-SIC (Sistema Eletrônico do Serviço de Informação ao Cidadão). Depois de obter o acesso, foi feito o cadastro da solicitação para acesso ao banco de dados dos e-mails dos diretores de escolas públicas do Brasil. Essa primeira tentativa foi frustrada, pois a solicitação foi enviada pelo sistema, erroneamente, ao INEP. Após cadastramento de nova solicitação, a demanda foi enviada à área correta no Ministério da Educação - MEC. Posteriormente aos trâmites legais, a base de dados foi liberada para acesso. O processo de acesso a essa informação levou mais de dois meses. A base de dados forneceu 133.694 e-mails cadastrados.

Conforme explicitado nos objetivos, geral e específicos, será analisada a sensibilidade intercultural dos diretores de escolas públicas do Brasil. Este diagnóstico se dará por uma análise de regressão. O processo de análise da sensibilidade intercultural é multifacetado, cujos aspectos são resultado de uma interação dinâmica entre elementos individuais, localizacionais e institucionais dos diretores.

A metodologia utilizada tem o objetivo de realizar os objetivos - geral e específicos - da pesquisa, de forma a oferecer uma resposta à pergunta desta pesquisa. A estrutura desta seção abordará: i) a caracterização geral da pesquisa, incluindo a finalidade, o caráter e a fonte de evidência da pesquisa a ser realizada; ii) a estratégia de pesquisa; e iii) a operacionalização da pesquisa, onde serão abordados o modelo conceitual e suas variáveis e as fases de coleta e de análise de dados. 
A pesquisa analisa os diretores das escolas, se eles reconhecem, compreendem e valorizam o culturalmente distinto em sua prática pedagógica. O processo de análise da sensibilidade intercultural é multifacetado, cujos aspectos são resultado de uma interação dinâmica entre elementos individuais, localizacionais e institucionais dos diretores.

\subsection{Questionário}

Este estudo é baseado em dados primários oriundos da aplicação de um questionário semiestruturado.

Segundo Godoy (1995), um questionário é um instrumento de investigação que visa recolher informações baseando-se, geralmente, na inquirição de um grupo representativo da população em estudo. Para tal, coloca-se uma série de questões que abrangem um tema de interesse dos investigadores, não havendo para respostas, interação direta entre estes e os inquiridos.

O autor Chisnall (1980) conceitua questionário como um método de obter informação específica sobre um problema definido de modo que, os dados, após análise e interpretação resultem em melhor apreciação do problema. Para Kinnear e Taylor (1991), é um roteiro formalizado para coleta de dados dos respondentes .A Figura 2 mostra o papel do questionário no projeto de pesquisa.

Figura 2 - Representação da ligação entre necessidade de informação e dados

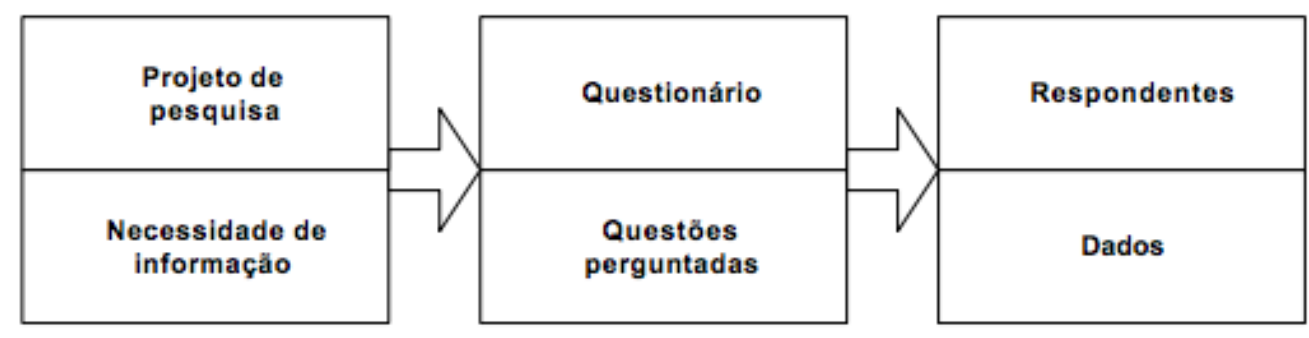

Fonte : Kinnear \& Taylor (1991, p.340)

Analisando a figura, constata-se que construir um questionário é uma tarefa árdua. Parasuraman (1991) diz que apesar de parecer uma tarefa simples, principalmente para aqueles que nunca desenharam um anteriormente. Kinnear e Taylor (1991) acrescentam que o desenho de um questionário é mais uma arte do que um empreendimento científico. 
O questionário foi dividido em dois blocos. O primeiro bloco de perguntas contém 18 questões. Ele é um questionário misto que contém uma pergunta aberta e o restante são perguntas fechadas. Foi realizado com o objetivo de relacionar as características demográficas, localizacionais e socioeconômicas dos respondentes, tais como idade, sexo, cor da pele, estado civil, estado de origem, estado onde atualmente reside, faixa salarial, grau de instrução, entre outras.

Assim, será possível conhecer o perfil dos diretores de escola pública em relação à sua sensibilidade intercultural.

No segundo bloco, as perguntas tem o objetivo de situar em qual grau de sensibilidade intercultural o respondente se encontra. Este bloco contém 30 questões. Elas foram baseadas nos trabalhos de Bennett $(1986,1993 b, 2004)$ referentes à sensibilidade intercultural. As questões são fechadas, respondidas em formato Likert . O Questionário encontra-se no apêndice A.

As respostas foram ranqueadas com a finalidade de se discriminar quais respondentes apresentam maior ou menor sensibilidade intercultural de acordo com a escala do DMIS. Assim, será possível verificar se diretores do país tem uma tendência etnocentrista ou etnorelativistas.

Esse questionário buscou - baseado na literatura de Bennett, Hammer, Wiseman e outros autores - captar qual a percepção que os respondentes tem em relação às relações humanas e ao mundo ligados a cultura, e mais especificamente, no caso de indivíduos advindos de culturas distintas, mensurar o grau de sensibilidade intercultural.

\subsubsection{Pré - Teste}

Em consonância ao que prega a maioria das fontes bibliográficas sobre metodologia de pesquisa consultada, optou-se por aplicar o questionário seis pessoas, que apresentaram características parecidas com o público alvo, configurando um pré-teste. É importante a realização do pré-teste após a elaboração do questionário a fim de avaliar a aceitabilidade, clareza, entendimento, tempo de resposta e redução do número de itens. Através deste procedimento, percebeu-se a necessidade de correções e aperfeiçoamentos para tornar a pesquisa mais inteligível e concisa, para a aplicação definitiva. Basicamente, foi aperfeiçoada a redação das questões, tornando-as mais claras e o mais objetivas possível para o entendimento do entrevistado. O tempo gasto para realização do pré-teste foi entre 10 e 20 minutos. Os resultados de pesquisa do pré-teste foram descartados. 
Parasuraman (1991, p. 396) aponta que o pré teste não deve ser visto como substituto para o cuidado e o rigor no desenvolvimento do questionário, nem tampouco como uma simples procura de erros que possam existir. Deve ser visto como uma ferramenta destinada aos últimos retoques do trabalho, confirmando a clareza das instruções, a abrangência das alternativas e outros detalhes.

\subsection{O Sistema LimeSurvey}

Utilizou-se o sistema de pesquisa LimeSurvey para aplicaçãoo do questionário e coleta de dados. Esse sistema é um software livre desenvolvido com o objetivo de preparar, publicar e coletar respostas de questionários. Uma vez criado um questionário, ele pode ser publicado Online (questão por questão, grupo a grupo de questões ou tudo em uma única página de questionários). O Limesurvey permite definir como as questões serão mostradas e variar o formato dos questionários por meio de um sistema de padrões ( templates ). Fornece ainda uma análise estatística básica sobre os resultados dos questionários.

Outra funcionalidade relevante, é a capacidade de gerar Tokens individualizados (chaves), de forma que apenas a pessoa que receber um token poderá acessar o questionário. Tokens são informações enviadas para a lista de pessoas, que você quer convidar para participar de um questionário, de forma a permitir maior controle do questionário disponibilizado pela Internet. Optou-se pela opção com controle de acesso. Para que apenas quem recebeu um convite, no caso, diretores de escolas públicas do Brasil, conseguissem responder e enviar as respostas.

\subsubsection{Levantamento de dados}

O questionário foi colocado no ar, através do LimeSurvey em outubro de 2016. Os convites para o entrevistado responder a pesquisa foram enviados via e-mail, dentro do sistema LimeSurvey. Conforme a disponibilidade dos entrevistados em responder, o banco de dados foi ganhando corpo.

\subsection{Amostra}

A amostra é composta pelos diretores de escolas públicas de educação básica do Brasil. Foram obtidos 133.694 e-mails, de escolas públicas, através da base de dados fornecida 
pelo MEC. Estes e-mails são utilizados no FNDE/MEC para contato com os diretores no projeto PDDE/Interativo.

Segundo Censo escolar de 2015, existem 149.098 escolas públicas de educação básica no Brasil. Conforme pode ser consultado na tabela 1, abaixo. O Censo Escolar é um levantamento de dados estatísticos educacionais de âmbito nacional realizado todos os anos e coordenado pelo Inep. Ele é feito com a colaboração das secretarias estaduais e municipais de educação e com a participação de todas as escolas públicas e privadas do país.

Tabela 1 - Número de escolas de educação básica por dependência administrativa Brasil 2008/2014

\begin{tabular}{|c|c|c|c|c|c|c|c|c|}
\hline \multirow{4}{*}{ Ano } & Vúmero de e & is de edt & Bação & $\begin{array}{l}\text { ásica por de } \\
2008 / 2014\end{array}$ & endência & ministrativ & & \\
\hline & \multicolumn{8}{|c|}{ Escolas de educação básica } \\
\hline & \multirow{2}{*}{ Total geral } & \multicolumn{5}{|c|}{ Pública } & \multirow{2}{*}{ Privada } & \multirow{2}{*}{$\%$} \\
\hline & & Total & $\%$ & Federal & Estadual & Municipal & & \\
\hline 2008 & 199.761 & 164.623 & 82,4 & 265 & 32.792 & 131.566 & 35.138 & 17,6 \\
\hline 2010 & 194.939 & 158.650 & 81,4 & 344 & 32.160 & 126.146 & 36.289 & 18,6 \\
\hline 2012 & 192.676 & 154.616 & 80,2 & 490 & 31.397 & 122.729 & 38.060 & 19,8 \\
\hline 2014 & 188.673 & 149.098 & 79,0 & 543 & 30.758 & 117.797 & 39.575 & 21,0 \\
\hline$\Delta \% 2008 / 2014$ & $-5,6$ & $-9,4$ & & 104,9 & $-6,2$ & $-10,5$ & 12,6 & \\
\hline
\end{tabular}

Fonte : Censo Escolar (2015)

A base de dados representa $89,6 \%$ das escolas do Censo. Entretanto, apesar de ter-se disponível 133.694 e-mails na base de dados, o sistemas só permitiu que fossem incluídos 116.780 e-mails em sua estrutura. O que representa 78,3\% dos dados do Censo. Esse foi o limite aceito, o sistema é satisfatória, mas esbarra em alguns entraves.

Obteve-se um total de 10.084 diretores respondentes.

Os dados dos e-mails estavam divididos por estados e Distrito Federal. Por desconhecerse a capacidade do sistema, optou-se por fazer um tratamento aleatório e fundamentalmente estatístico dos dados. O objetivo desta ação, foi precaver-se de uma situação em que o sistema chega-se a capacidade máxima antes de ter a representação mínima de todos os estado. Os dados aleatórios permitiriam que a amostra tenha a representação de todos. 
Os dados foram organizados através de tabelas, foram calculadas médias, medianas, modas, desvios-padrões e frequências das respostas.

\subsection{Envio de dados}

A participação dos Diretores foi vital para a construção desta pesquisa. O envio de e-mails foi feito através do LimeSurvey. E apesar de ser uma boa ferramenta, ela só permitiu o envio dos convites de participação em blocos de 250 e-mails. Com um total de 116.780 convites a serem enviados, foi necessário realizar 468 envios para que todos pudessem recebe-los. Atividade que gerou um elevado custo de tempo, maior que o previsto.

Foram enviados dois lembretes, também através do LimeSurvey. Eles tiveram o objetivo de sensibilizar os diretores de escolas a participarem da pesquisa. Nesse momento o Sistema permitiu envio em blocos de 500 e-mails. O que reduziu pela metade o tempo de envio de cada lembrete. O modelo de e-mail do convite e dos lembretes encontram-se nos apêndices $\mathrm{B}$ e $\mathrm{C}$ deste trabalho.

Notou-se que a maior parte das resposta chegavam a base de dados assim que os convites e lembretes eram enviados.

O Fluxo destes envios, está representado na Figura 3, abaixo.

Figura 3 - Fluxo de e-mails aos Diretores de Escolas Públicas

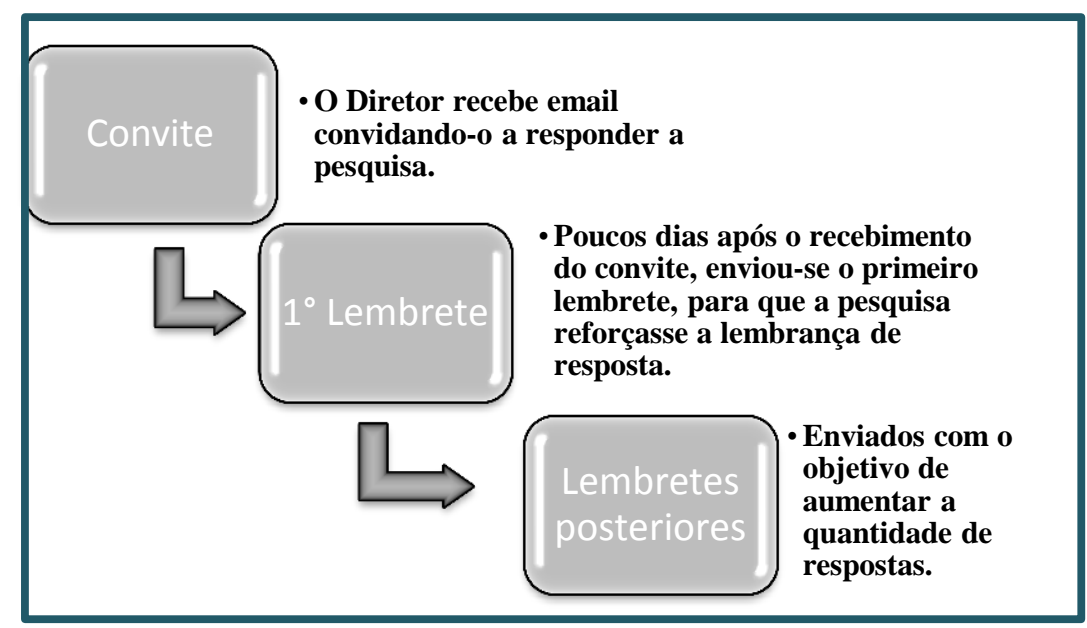

Fonte : Dados da pesquisa 


\section{4. Índice de Sensibilidade Intercultural (ISI)}

O Índice de Sensibilidade Intercultural (ISI) foi mensurado através das perguntas elaboradas. Elas obtiveram a relação dos diretores com culturas distintas, e de que forma esse indivíduo se relaciona, enxerga e compreende um indivíduo que tenha outra origem. Essa pesquisa se baseou em parte da metodologia de Damasceno et al (2011) e na teoria de Hammer et. al (2003). Pode-se definir, matematicamente, o ISI como:

$I S I=\sum_{i=1}^{30} c_{i}$

Em que: $\quad-60 \leq I S I \leq 60 \quad$ e $\quad-2 \leq c_{i} \leq 2$

Onde:

ISI = Índice de Sensibilidade Intercultural; e,

$C_{i}=$ contribuição da pergunta "i" - em escala Likert - no Índice de Sensibilidade Intercultural dos diretores de escolas públicas de educação básica.

As perguntas do questionário serão utilizadas para indicadores, com variáveis e seus respectivos pesos.

\subsection{Modelo Econométrico}

O objetivo desta etapa é identificar a contribuição de cada variável independente sobre a capacidade preditiva da sensibilidade intercultural como um todo. O modelo será ajustado utilizando a forma funcional de mínimos quadrados ordinários, uma reta que minimiza a soma dos quadrados dos resíduos será utilizada para resumir a relação linear entre Y(sensibilidade intercultural) e Xi(variáveis independentes).

Montgomery et al. (2001) definem regressão linear como uma técnica estatística para modelar e investigar a relação entre variáveis.

O modelo de regressão linear pode ser apresentado como:

$$
\mathrm{Y}=\beta_{0}+\beta \mathrm{ixi}+\epsilon
$$

Em que:

Y - Variável dependente;

$\beta 0$ - é a constante de intercepto;

$\beta_{\mathrm{i}}$ - são os parâmetros estimados; 
$\mathrm{X}_{\mathrm{i}}$ - Variáveis independentes (Fruto do questionário)

$\epsilon-$ Erro

O termo $€$ é o erro aleatório, assumido como normal e independentemente distribuído, com média zero e variância $\left(\boldsymbol{\sigma}^{2}\right)$ constante e desconhecida. A figura 4 ilustra o modelo de regressão linear apresentado.

Figura 4 - Modelo de reta de regressão linear

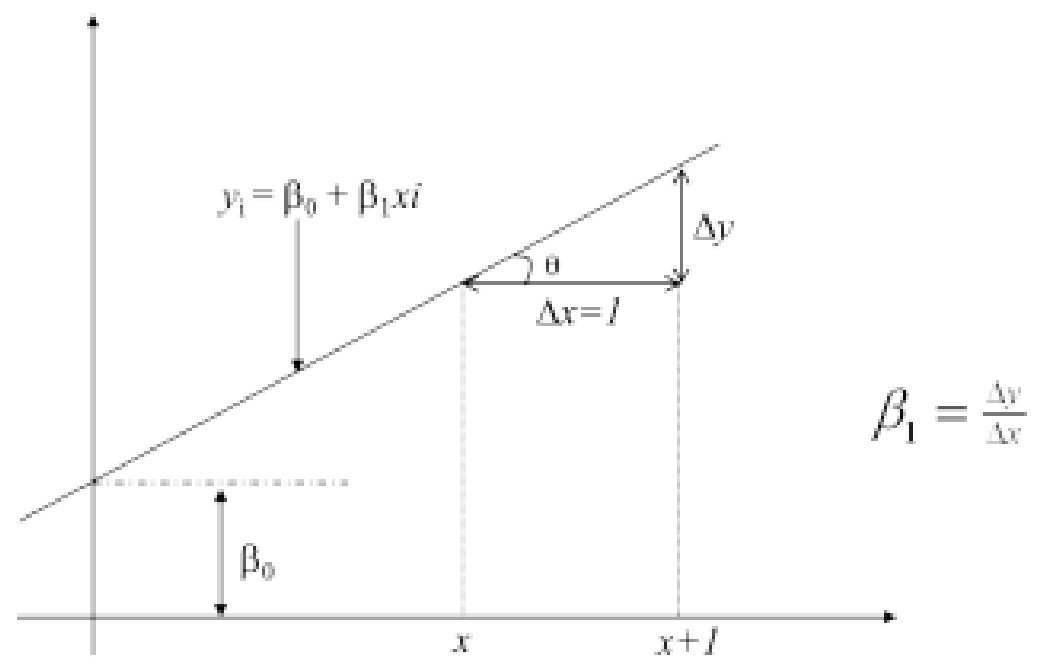

Fonte : Dados da Pesquisa

Nessa contexto, a variável dependente é o ISC.

\subsubsection{Regressão Linear}

Naghettini e Pinto (2007) esclarecem que a análise de regressão consiste na realização de uma análise estatística com o objetivo de verificar a existência de uma relação funcional entre uma variável dependente com uma ou mais variáveis independentes. Bussab e Morettin (2009) afirmam que a análise de regressão é uma técnica estatística cujo escopo é investigar e modelar a relação entre variáveis .

A regressão linear múltipla é uma variação mais frequente da regressão linear. É um conjunto de técnicas estatísticas que possibilitam a avaliação de uma variável dependente com diversas variáveis independentes. O resultado é uma equação linear que pode ser utilizada para estimar a variável dependente como uma combinação linear das independentes. A diferença entre 
esta e a regressão simples é que possui mais de uma variável. Na equação o k é o número de variáveis independentes, na regressão simples $\mathrm{k}=1$.

$$
y=\beta 0+\beta 1 x 1+\beta 2 x 2+\ldots+\beta k x k+\varepsilon
$$

Os parâmetros $\beta 0, \beta 1, \ldots, \beta \mathrm{k}$ da equação acima são os coeficientes de regressão, onde $\beta 0$ é o intercepto da reta no eixo da ordenada e $\beta 1, \ldots, \beta$ i é a inclinação da reta.

\subsubsection{Método dos Mínimos Quadrados}

A reta obtida no modelo é estimada. Existem diversas técnicas para a obtenção da reta desejada. A mais usual é a chamado "técnica do ajuste visual". Ela resume-se em traçar diretamente a reta, com auxílio de uma régua, no diagrama de dispersão, fazendo-a passar por entre os pontos, da melhor forma possível. Por ser um procedimento subjetivo somente será plausível se a correlação linear for muito forte. A figura 5 ilustra uma reta de regressão.

Figura 5 - Representação da Reta de Regressão

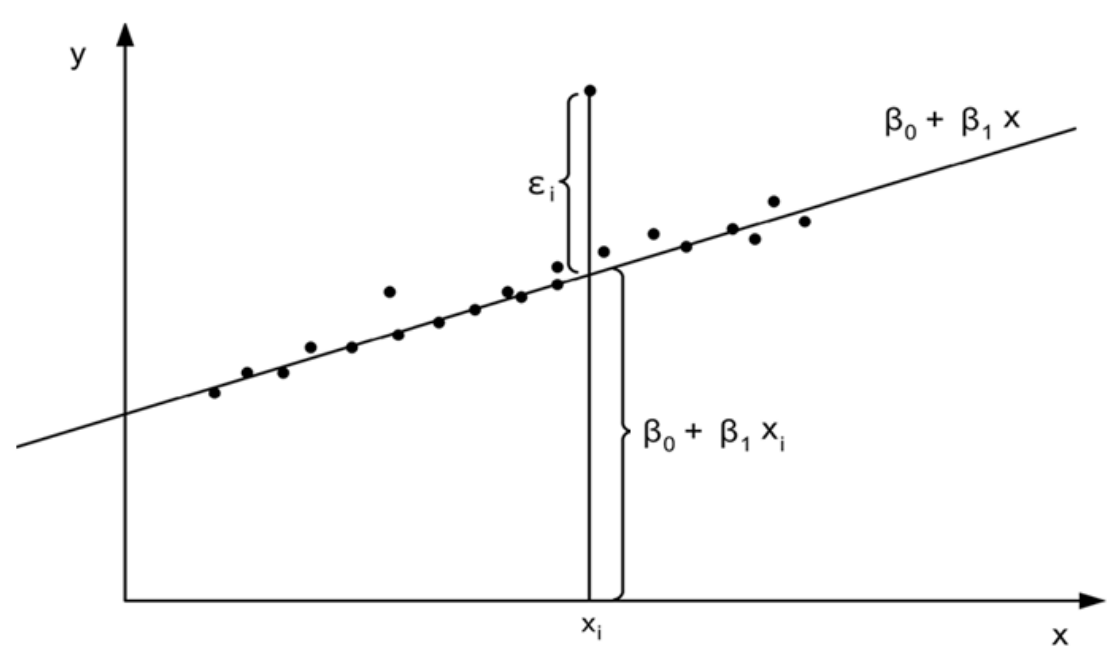

Fonte : Dados da Pesquisa

Os autores Black, Paez e Suthanaya (2002) afirmam que os parâmetros deste modelo básico podem ser estimados pela técnica bem conhecida de mínimos quadrados, o que minimiza a soma quadrado de erros.

De uma forma mais técnica, quando o número de observações (n) for maior que o número de variáveis independentes (k), o método mais usual para estimar a equação de regressão é o 
método dos mínimos quadrados ordinários - MQO. Esse método estima os parâmetros de regressão de forma a minimizar as somas quadráticas dos resíduos (MONTGOMERY et al., 2001; NETER et al., 2004; WEISBERG, 2005).

$$
y^{\wedge}=\beta 0+\beta 1 x 1+\beta 2 x 2+\ldots+\beta k x k+\varepsilon
$$

De acordo com Montgomery et al. (2001) e Weisberg (2005), o y^ são os valores estimados para y da equação anterior. A diferença entre as duas variáveis são os resíduos $\varepsilon$.

$$
\varepsilon i=y-y^{\wedge}
$$

Algumas das variáveis independentes fruto do questionário, tais como: idade, sexo, renda, religião que segue ou professa, unidade federativa de origem, entre outras serão dummies, que segundo Gujarati (2006), são variáveis do tipo qualitativas que assumem os valores de 0 ou 1. Com o estimador de Mínimos Quadrados Ordinários - MQO, tentará se obter uma a melhor representação da variável dependente em relação as variáveis independentes, minimizando a soma dos quadrados dos erros, segue abaixo:

$$
\operatorname{Min}\left[\sum_{i=1}^{n}{\boldsymbol{\varepsilon}^{\prime}}_{\boldsymbol{i}}^{2}\right]=\operatorname{Min}\left[\sum_{t=1}^{n}\left(y_{t}-y_{t}^{\prime}\right)^{2}\right]
$$

Onde:

$y_{t}=$ Valor real observado de cada observação da variável dependente;

$y_{t}^{\prime}=$ Valor previsto pela reta de regressão;

$\boldsymbol{\varepsilon}^{\prime}{ }_{i}=$ Erro ou resíduo, que é a diferença entre o valor real observado e o previsto na reta de regressão;

$\mathrm{n}=$ Número de observações na amostra.

Neste trabalho pretende-se atender às seguintes premissas: a amostra deve ser aleatória; haja linearidade entre os parâmetros; os resíduos possuam distribuição normal e não sejam correlacionados, haja homocedasticidade entre os resíduos e que não haja multicolinearidade entre as variáveis independentes. (GUJARATI, 2006).

A partir dos estimadores encontrados pelas regressões de MQO será possível conhecer o perfil dos diretores de escola pública de educação básica em relação à sensibilidade intercultural. 


\subsubsection{Multicolinearidade}

Uma das suposições para o modelo de regressão é a independência entre as variáveis de controle do modelo de regressão, já que quando a correlação entre as variáveis é significativa, as inferências para o modelo de regressão são errôneas. Quando existem dependências lineares entres as variáveis de controle do modelo, diz-se que existe a presença de multicolinearidade (MONTGOMERY et al., 2001; NETER et al., 2004).

A multicolinearidade dificulta a separação do efeito que cada uma das variáveis exerce sobre a variável dependente, prejudicando a habilidade preditiva do modelo de regressão. Um dos sinais da sua existência é quando o teste $\mathrm{F}$ de significância do modelo de regressão indica que é estatisticamente significante, mas nenhum dos testes t indica a significância dos coeficientes de inclinação. Podem ser feitos alguns testes para indicar a presença ou não da multicolinearidade, entre eles o VIF (fator de inflação da variância) que deve apresentar valores entre 5 e 10, no máximo (NETER et al., 2004).

\subsubsection{Variáveis "Dummy"}

As variáveis usadas nas equações de regressão podem não serem quantitativas. Para as variáveis que apresentam um aspecto dicotômico, ou seja, que sempre dizem respeito ao acontecimento ou não de um evento genérico. Se convencionou, geralmente usar-se o número um quando determinada característica está presente e o número zero em caso contrário (Moreira Filho, 1993, p.85-87).

O autor Johnston (1974) infere que dentro de uma regressão da variável dependente sobre as variáveis independentes "dummy", os coeficientes de mínimos quadrados das variáveis “dummy” são as médias das celas em que estão tabulados .

\subsubsection{Testes de Hipóteses}

A estimativa da variância $\left(\sigma^{2}\right)$ é crucial para a realização do teste de hipóteses e para a construção do intervalo de confiança. Para os autores Montgomery et.al (2001) e Weisberg (2005 ), essa estimativa pode ser obtida pelo quadrado médio dos erros (QMR).

$$
\sigma^{\wedge 2}=\frac{S Q R}{n-p}=Q M R
$$


A tabela 2 expressa a análise de variância (ANOVA). Segundo Montgomery et.al (2001) e Neter et al. (2004), serve para testar a significância da regressão, ou seja, para verificar a existência de relação linear entre variável dependente e variáveis explicativas.

Tabela 2 - ANOVA

\begin{tabular}{llccc}
\hline Fonte de & $\begin{array}{l}\text { Soma dos } \\
\text { Variação }\end{array}$ & $\begin{array}{c}\text { Graus de } \\
\text { Quadrados }\end{array}$ & $\begin{array}{c}\text { Média } \\
\text { Luadrática }\end{array}$ & $F_{0}$ \\
\hline Regressão & SQReg & K & QMReg=SQReg/k & QMReg/QMR \\
Resíduos & SQR & n-p & QMR=SQR/(n-p) & \\
Total & SQT & n-1 & & \\
\hline
\end{tabular}

O teste de significância da regressão pode ser expresso pelas seguintes hipóteses:

$$
\begin{gathered}
\mathrm{H} 0: \beta 1=\beta 2=\ldots=\beta \mathrm{k}=0 \\
\mathrm{H} 1: \beta \mathrm{j} \neq 0 \text { para no mínimo um } \mathrm{j} .
\end{gathered}
$$

O descarte da hipótese nula (H0) significa que ao menos uma das variáveis de controle é estatisticamente significativa para o modelo. O teste de significância da regressão é baseado na decomposição da soma dos quadrados totais (SQT) equação XX.

$$
\mathrm{SQT}=\mathrm{SQR}+\mathrm{SQReg}
$$

De acordo com Montgomery et al. (2001) e Neter et al. (2004) afirmam que:

Os graus de liberdade para análise de variância são distribuídos da seguinte maneira: A SQT possui n - 1 graus de liberdade; A SQReg possui $k$ graus de liberdade. É definido pelos $k$ coeficientes de inclinação do modelo; A SQR possui $n$ - p graus de liberdade, a estimativa de cada um dos p parâmetros do modelo acarreta a perda de um grau de liberdade. Para testar as hipóteses da equação 3.6, utiliza-se o seguinte teste (MONTGOMERY et al., 2001; NETER et al., 2004):

É utilizado o seguinte teste, com o objetivo de testar as hipóteses:

$$
F_{0}=\frac{Q M R e g}{Q M R}
$$

Esta estatística, equação XX apresenta uma distribuição F-Snedecor com k graus de liberdade no numerador e $\mathrm{n}-\mathrm{n}$ no denominador. Para rejeitar a hipótese nula H0, isto é, mostrar 
que existe uma relação linear entre os preditores e o preditando, a seguinte expressão deve ser verdadeira:

\section{$\mathrm{F} 0>\mathrm{F} \boldsymbol{\alpha}, \mathbf{K}, \mathbf{n}-\mathbf{p}$}

Segundo Montgomery e Runger (2003), os coeficientes de regressão também devem ser testados com a formulação de hipóteses e a construção de intervalos de confiança. Para isso, pode-se montar o seguinte teste :

$$
\begin{aligned}
& \mathrm{H} 0: \beta \mathrm{j}=c t e \\
& \mathrm{H} 1: \beta_{\mathrm{j}} \neq c t e
\end{aligned}
$$

Para esse teste utiliza-se a estatística H0, de acordo com Montgomery et al. (2001), Neter et al. (2004), Weisberg (2005) essa estatística segue uma distribuição t-student com n - p graus de liberdade. A hipótese nula Ho é rejeitada se:

$$
\left|t_{0}\right|>t_{\alpha} / 2, n-p
$$

Um caso particular é quando a constante testada na equação 3.10 é zero, neste caso:

$$
\begin{gathered}
\mathrm{H} 0: \beta \mathrm{j}=0 \\
\mathrm{H} 1: \beta \mathrm{j} \neq 0
\end{gathered}
$$

Se no teste de hipótese acima $\mathrm{H} 0$ for aceita, a variável de controle xj não é estatisticamente significante e deve ser retirada da equação de regressão. Para que sejam tomadas decisões sobre H0 pode ser utilizado o (p-value). Montgomery e Runger (2003) definiram esse como o menor nível de significância que conduz à rejeição da hipótese nula H0 com os dados fornecidos. Nesse caso, quando o valor $\mathrm{p}$ for menor que o nível de significância adotado existem evidências estatísticas suficientes para se rejeitar Ho.

\subsubsection{Coeficientes de Avaliação e Qualidade do Modelo}

MONTGOMERY et al. (2001) e Weisberg (2005) conceituam coeficiente de determinação como a medida de variabilidade que pode ser explicada pelo modelo a seguir: 


$$
R^{2}=\frac{S Q R e g}{S Q T}=1-\frac{S Q R}{S Q T}
$$

Em que $: 0 \leq R^{2} \leq 1$

A raiz quadrada de $R^{2}$ é o coeficiente de regressão múltipla entre y e o conjunto de variáveis de controle utilizadas no modelo. O coeficiente de determinação ajustado é uma medida de controle que leva em consideração tanto a variabilidade de y que é explicada pelo modelo quanto o número de variáveis de controle utilizado (MONTGOMERY et al., 2001; NETER et al., 2004):

$$
R_{\alpha}^{2} j=1-\frac{n-1}{n-p}\left(1-R^{2}\right)
$$

Na equação o o acréscimo de uma variável ao modelo pode fazer com que $R_{\alpha}^{2} j$ decresça, se o aumento de $R^{2}$ não for suficientemente grande para compensar a perda de um grau de liberdade em n - p (MONTGOMERY; RUNGER, 2003).

Será analisado o $R^{2}$ ajustado $\left(R_{\boldsymbol{\alpha}}^{2} j\right)$, devido ao número de variáveis independentes ser diferente nos modelos analisados, traduzindo a percentagem da variável dependente que é explicada através das varáveis explicativas.

O coeficiente de determinação $R^{2}$ ajustado $\left(R_{\boldsymbol{\alpha}}^{2} j\right)$, tende a ser influenciado pela dimensão da amostra e ser influenciado pela dispersão existente nos dados, sendo uma medida optimista da qualidade do ajustamento feito.

\subsubsection{Testes de significância}

A Regressão Linear Múltipla deve passar pela análise de todos os pressupostos, seguidos dos seguintes testes:

\section{- Teste de significância global}

Testar-se-á se o modelo é globalmente significativo, ou seja, se o modelo na sua globalidade tem capacidade explicativa. Este teste será efetuado através do F de Snedcor, onde: 


$$
F=\frac{S S R / k}{S S E /(n-k-1)}
$$

Média Quadrática da Regressão : $\frac{S S R}{k}$

Em que :

SSR - variação explicada pelo modelo de regressão

$\mathrm{k}$ - número de graus de liberdade

Média Quadrática Residual: $\frac{S S E}{n-k-1}$

Em que :

SSE - variação não explicada pelo modelo de regressão

\section{- Teste de significância individual}

As variáveis explicativas são analisadas verificando se a mesma tem capacidade explicativa no modelo obtido. Este teste é efetuado através da distribuição t de Student.

É testada a hipótese dos $\beta$ 's serem iguais a um valor fixo, ou seja se estes assumem o valor "0".

Em seguida, a partir das evidências encontradas, será possível orientar políticas públicas nos sentido de trazer alguma contribuição para o processo da gestão escolar ou até mesmo para a produção de conhecimento. 


\section{Análise de Resultados}

A presente sessão tem por objetivo apresentar e discutir os resultados obtidos neste trabalho. Para a análise, conforme apresentado no capítulo anterior, foram aplicados questionários junto aos diretores de escolas públicas do Brasil, e a partir das informações obtidas, construído um Índice de Sensibilidade Intercultural - ISI, em seguida, feitas regressões de MQO com o objetivo de buscar evidências a respeito de quais características desses diretores influenciam no referido índice. O principal objetivo deste projeto é mensurar o grau de sensibilidade intercultural dos diretores e buscar evidências sobre quais características individuais, institucionais e localizacionais influenciariam na sensibilidade intercultural desses gestores da educação.

Com o objetivo de se conhecer melhor a amostra dos respondentes do questionário, inicialmente são apresentadas as estatísticas descritivas. A Tabela 3 apresenta média, mediana, moda, desvio padrão (DP) e os valores máximos e mínimos das variáveis consideradas nos modelos de regressão. 
Tabela 3 - Estatísticas Descritivas do Grupo de Diretores de Escolas Públicas

\begin{tabular}{|c|c|c|c|c|c|c|}
\hline Variável & Média & Mediana & Moda & DP & Máximo & Mínimo \\
\hline ISI & 27,43 & 26 & 22 & 9,62 & 55 & -25 \\
\hline Idade & 44,29 & 45 & 49 & 8,47 & 75 & 19 \\
\hline Sexo & 0,23 & 0 & 0 & 0,42 & 1 & 0 \\
\hline Solteiro & 0,17 & 0 & 0 & 0,38 & 1 & 0 \\
\hline Casado & 0,60 & 1 & 1 & 0,49 & 1 & 0 \\
\hline Divorciado & 0,10 & 0 & 0 & 0,3 & 1 & 0 \\
\hline Viúvo & 0,02 & 0 & 0 & 0,15 & 1 & 0 \\
\hline União & 0,09 & 0 & 0 & 0,28 & 1 & 0 \\
\hline Ensino Fundamental & 0,001 & 0 & 0 & 0,04 & 1 & 0 \\
\hline Ensino Médio & 0,02 & 0 & 0 & 0,13 & 1 & 0 \\
\hline Ensino Superior & 0,24 & 0 & 0 & 0,43 & 1 & 0 \\
\hline Especialização & 0,69 & 1 & 1 & 0,46 & 1 & 0 \\
\hline Mestrado & 0,04 & 0 & 0 & 0,21 & 1 & 0 \\
\hline Doutorado & 0,005 & 0 & 0 & 0,07 & 1 & 0 \\
\hline Salários mínimos & 4,39 & 4 & 4 & 1,91 & 9 & 0 \\
\hline Filhos & 1,72 & 2 & 2 & 1,16 & 7 & 0 \\
\hline Religião Católica & 0,65 & 1 & 1 & 0,48 & 1 & 0 \\
\hline Protestante & 0,18 & 0 & 0 & 0,38 & 1 & 0 \\
\hline Asiática & 0,001 & 0 & 0 & 0,04 & 1 & 0 \\
\hline Mulçumana & 0,001 & 0 & 0 & 0,02 & 1 & 0 \\
\hline Judaica & 0,001 & 0 & 0 & 0,03 & 1 & 0 \\
\hline Africana & 0,01 & 0 & 0 & 0,12 & 1 & 0 \\
\hline Outras religiões & 0,26 & 0 & 0 & 0,44 & 1 & 0 \\
\hline Cor Branca & 0,55 & 1 & 1 & 0,5 & 1 & 0 \\
\hline Parda & 0,36 & 0 & 0 & 0,48 & 1 & 0 \\
\hline Negra & 0,08 & 0 & 0 & 0,27 & 1 & 0 \\
\hline Asiático & 0,005 & 0 & 0 & 0,07 & 1 & 0 \\
\hline Indígena & 0,01 & 0 & 0 & 0,07 & 1 & 0 \\
\hline Televisão & 1,36 & 1 & 1 & 0,96 & 5 & 0 \\
\hline Jornalismo & 0,87 & 1 & 1 & 0,34 & 1 & 0 \\
\hline Programas Esportivos & 0,19 & 0 & 0 & 0,39 & 1 & 0 \\
\hline Novelas & 0,27 & 0 & 0 & 0,45 & 1 & 0 \\
\hline Filmes & 0,45 & 0 & 0 & 0,5 & 1 & 0 \\
\hline Programas de Auditório & 0,11 & 0 & 0 & 0,31 & 1 & 0 \\
\hline Outros programas de TV & 0,25 & 0 & 0 & 0,44 & 1 & 0 \\
\hline Número de Computadores & 2,37 & 2 & 1 & 1,37 & 5 & 0 \\
\hline Horas de Internet & 2,9 & 3 & 5 & 1,69 & 5 & 0 \\
\hline Viagens ao Exterior & 0,57 & 0 & 0 & 1,17 & 5 & 0 \\
\hline Residência no exterior & 0,02 & 0 & 0 & 0,14 & 1 & 0 \\
\hline Migração entre Estados & 0,14 & 0 & 0 & 0,35 & 1 & 0 \\
\hline
\end{tabular}

Fonte: Dados da Pesquisa

É importante notar que algumas das variáveis descritas na Tabela 1 são categóricas. Assim, obviamente, as estatísticas de média, moda, etc., representam os valores assumidos pelas dummies. 
Observe que do total de 10.084 diretores respondentes, $23 \%$ deles são do sexo masculino, sendo, portanto, a grande maioria de respondentes da pesquisa formada de mulheres.

Ainda observando a Tabela 1, no que diz respeito a variável estado civil, observa-se que $17 \%$ dos diretores respondentes se declararam solteiros, $60 \%$ casados, $10 \%$ divorciados, $2 \%$ viúvos e 9\% união estável.

Com relação à escolaridade, os diretores com nível fundamental representam $0,1 \%$ da amostra, em torno de 10 indivíduos. Da amostra 2\% declarou ter nível médio, 24\% nível superior, $69 \%$ especialização, $4 \%$ mestrado e $0,5 \%$ doutorado. Há mais indivíduos com doutorado, do que apenas nível fundamental. A grande maioria tem nível superior e especialização (em torno de 93\%). Este fato revela que os diretores de escolas públicas respondentes da pesquisa, tem bom nível de grau de escolaridade.

No que diz respeito à religião, $65 \%$ dos diretores se declararam católicos, $18 \%$ protestantes.

Apenas 2\% dos diretores respondentes já residiram no exterior.

Ainda observando a referida tabela, verifica-se que o valor médio do ISI é de 27,43 pontos, enquanto que a mediana é de 26 pontos, a moda é de 22 pontos e os valores máximos e

mínimos são de 55 e -25 pontos, respectivamente. É importante lembrar que o ISI aqui proposto pode variar entre -60 e 60 pontos. O menor valor está relacionado ao comportamento etnocentrista e o maior ao comportamento etnorelativistas.

Ainda observando a Tabela 1, podem-se verificar as principais estatísticas descritivas do modelo.

\subsection{Resultados das Regressões}

A tabela 4 apresenta os resultados obtidos nos modelos de regressão MQO como os valores dos coeficientes das variáveis, assim como suas respectivas significâncias estatísticas, resultados de testes como o Durbin-Watson e F, e o valor do $\mathrm{R}^{2}$. 
Tabela 4 - Resultados dos Modelos de Regressão MQO

\begin{tabular}{|c|c|c|c|}
\hline Variáveis/Estatísticas & Modelo 1 & Modelo 2 & Modelo 3 \\
\hline Constante & $29,310 *$ & $29,624^{*}$ & $29,157 *$ \\
\hline Sexo & 0,257 & 0,264 & 0,282 \\
\hline Idade & $-0,269 *$ & $-0,278^{*}$ & $-0,264 *$ \\
\hline Idade ao quadrado & $0,003 * *$ & $0,003 * *$ & $0,002 * *$ \\
\hline Casado & $-0,908 *$ & $-0,980 *$ & $-0,958 *$ \\
\hline Divorciado & 0,207 & 0,108 & 0,128 \\
\hline Viúvo & $-0,937$ & $-1,006$ & $-0,954$ \\
\hline União Estável & $-0,215$ & $-0,272$ & $-0,234$ \\
\hline Fundamental e Médio & $-2,100 *$ & $-2,151^{*}$ & $-2,079 *$ \\
\hline Especialização & $0,958 *$ & $0,986^{*}$ & $0,996 *$ \\
\hline Mestrado e Doutorado & $2,884^{*}$ & $2,970 *$ & $2,915^{*}$ \\
\hline Salários mínimos & $0,274 *$ & $0,283^{*}$ & $0,281 *$ \\
\hline Filhos & $0,193 * *$ & $0,221 * *$ & $0,214 * *$ \\
\hline Protestante & $-1,975^{*}$ & $-1,906^{*}$ & $-1,927 *$ \\
\hline Asiática & 3,895 & 3,782 & 3,761 \\
\hline Mulçumana & 3,259 & 3,693 & 3,415 \\
\hline Judaica & $8,612 * *$ & $8,119 * *$ & $7,800 * *$ \\
\hline Africana & $4,851 *$ & $4,796^{*}$ & $4,834^{*}$ \\
\hline Outras Religiões & $0,914 * *$ & $0,882 * *$ & $0,884^{*}$ \\
\hline Parda & 0,012 & 0,137 & 0,042 \\
\hline Negra & $1,887 *$ & $2,006^{*}$ & $1,874^{*}$ \\
\hline Asiático & 1,383 & 1,578 & 1,413 \\
\hline Indígena & 0,549 & 0,795 & 0,639 \\
\hline Televisão & $-0,441 *$ & $-0,427 *$ & $-0,433 *$ \\
\hline Jornalismo & $0,699 * *$ & $0,685 * *$ & $0,683 * * *$ \\
\hline Esportivo & 0,042 & 0,040 & 0,046 \\
\hline Novelas & $-0,979 *$ & $-0,969 *$ & $-0,970 *$ \\
\hline Filmes & $1,000 *$ & $0,984 *$ & $0,984 *$ \\
\hline Auditório & $-0,151$ & $-0,155$ & $-0,162$ \\
\hline Outros programas de $\mathrm{TV}$ & $0,624 *$ & $0,613^{*}$ & $0,610^{*}$ \\
\hline Computador & $0,387 *$ & $0,380 *$ & $0,390 *$ \\
\hline Internet & $0,370^{*}$ & $0,362 *$ & $0,364 *$ \\
\hline Viagens ao Exterior & $0,563^{*}$ & $0,577 *$ & $0,574 *$ \\
\hline Residência no exterior & $2,813^{*}$ & $2,775^{*}$ & $2,765^{*}$ \\
\hline Migração entre Estados & 0,395 & $0,681 * *$ & $0,912 *$ \\
\hline UF Nascimento & Sim & Não & Sim \\
\hline UF Residência & Não & Sim & Sim \\
\hline $\mathrm{N}$ & 9854 & 9854 & 9854 \\
\hline $\mathrm{R}^{2}$ & 0,082 & 0,083 & 0,086 \\
\hline Teste F & $\begin{array}{r}14,583 \\
(0,000)\end{array}$ & $\begin{array}{l}14,745 \\
(0,000)\end{array}$ & $\begin{array}{c}10,721 \\
(0,000)\end{array}$ \\
\hline Durbin- Watson & 2,012 & 2,012 & 2,012 \\
\hline
\end{tabular}

Fonte: Dados da Pesquisa.

Notas: Estatisticamente significantes até $* 1 \%, * * 5 \%, * * * 10 \%$. Entre parênteses: significância.

Observe que a referida tabela apresenta três modelos que se distinguem com a inclusão e exclusão das Unidades da Federação - UFs que os respondentes identificaram como sendo 
àquelas de nascimento e residência. Assim, o Modelo 1 possui como variável de controle principal a UF de nascimento do respondente, o Modelo 2 a UF de residência e o Modelo 3 foi feita a inclusão das duas variáveis. O objetivo de tais variações é o de captar o efeito global dos locais de nascimento, residência e ambos na correlação do ISI do respondente.

Verifica-se que, de maneira geral, os resultados são aqueles que se esperavam não parecendo trazer nenhuma surpresas nas médias condicionais da regressão.

É importante observar que o ISI médio ficou em torno de vinte e sete, com $95 \%$ deles entre dezessete e trinta e sete, verificado a partir do valor de seu Desvio Padrão. Por outro lado, a mediana foi de vinte e seis e a moda de vinte e dois e os valores mínimos e máximos encontrados na amostra entre -25 e 55.

Inicialmente, pode-se verificar que a variável sexo não é estatisticamente significante para nenhum dos três modelos de regressão utilizados. Assim, não se poderia afirmar, com base na amostra obtida, que existam diferenças significativas de percepção entre diretores do sexo masculino e feminino. Alguém poderia imaginar que diretoras poderiam ter maior sensibilidade intercultural que diretores dado que mulheres são dotadas do dom da maternidade (ou por qualquer outra razão) poderiam se destacar neste aspecto. Entretanto, não se pode afirmar tal fato, assim como também o contrário, ainda que se pudesse guardar essa expectativa para os diretores do sexo masculino por alguma outra razão.

A Figura 6 apresenta o ISI Médio dos diretores respondentes por sexo. Observe que os diretores do sexo masculino apresentam maior índice comparado às diretoras.

Figura 6 - Índice de Sensibilidade Intercultural médio por sexo na amostra

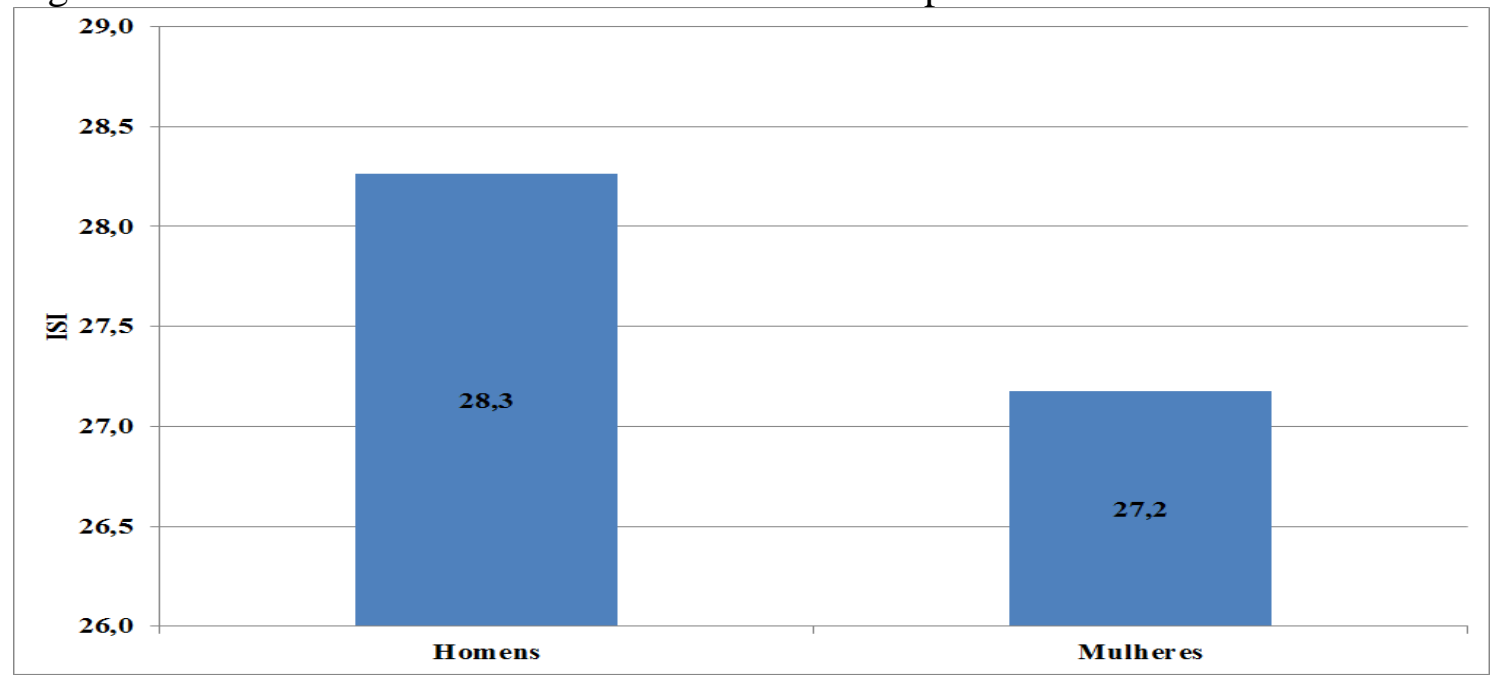


Fonte: Dados da Pesquisa

Observando a Figura 2, verifica-se que a diferença entre o ISI de diretores e diretoras respondentes é de 1,1 pontos. Na amostra os homens correspondem a $23 \%$ do total de respondentes.

No que diz respeito à idade, os resultados mostram que quanto maior a idade menos sensível se parece ser em relação às pessoas de culturas distintas. Tal fato, pode ocorrer pois o aumento da idade possivelmente traz a consolidação de crenças, e estas podem gerar diminuição da empatia por culturas distintas. Essa variável apresentou significância estatística ao nível de 1\% em todos os modelos de regressão. Entretanto, o modelo previu a captura de uma relação de não linearidade, incluindo a mesma variável idade ao quadrado que se apresenta estatisticamente significante. Quando se calcula a derivada parcial dos estimadores, verifica-se que se encontra um ponto de mínimo relativo em torno dos 50 anos de idade, mais precisamente 44,8; 46,3 e 66 anos para os Modelos 1, 2 e 3, respectivamente. Tais resultados fazem crer que a sensibilidade diminui com o passar dos anos até a faixa dos 45 anos de idade e depois dessa faixa etária volta a crescer. Tal fato pode estar relacionado com as mudanças vividas por pessoas que alcançam essa faixa etária quando consegue acumular maior cognição e vivência.

A Figura 7 apresenta a dinâmica do ISI estimado para o ciclo de vida de um diretor com as características típicas da amostra. Trata-se da estimação pontual da ISI, a partir do Modelo 3, para um indivíduo típico que é aquele formado pela mediana. 
Figura7 - Índice de Sensibilidade Intercultural médio por idade do indivíduo típico na amostra

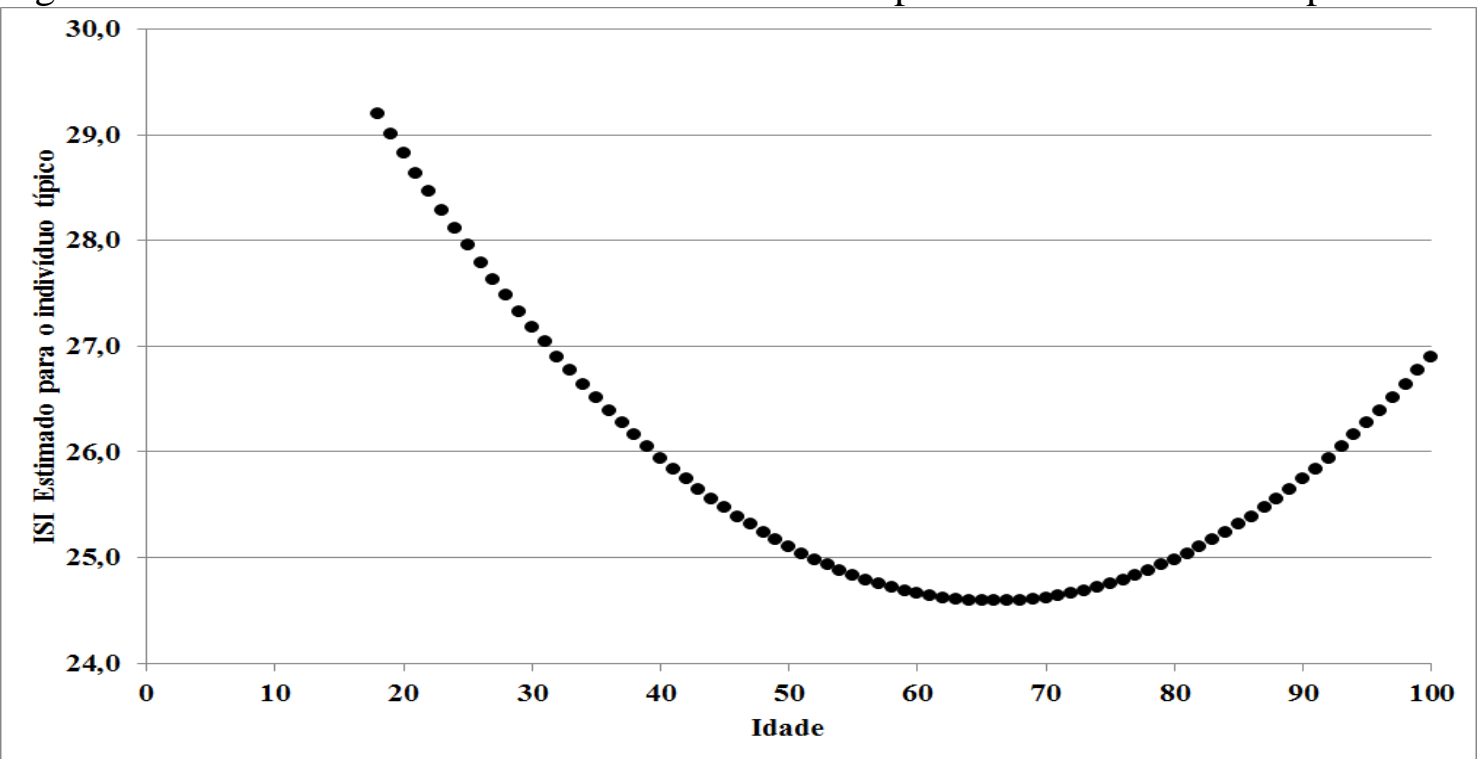

Fonte: Dados da Pesquisa

Conforme se verifica na referida figura à medida que os anos se passam os indivíduos passam a ter menor sensibilidade intercultural, entretanto, esse quadro se reverte depois que ele alcança certa faixa etária.

Com relação ao estado civil, foram inseridas quatro variáveis dummies para buscar evidências a respeito de qual dos tipos teriam maior impacto na determinação da ISI em comparação com os respondentes solteiros (grupo de comparação). Os resultados mostram que os respondentes que se declararam "Casado" possuíam menor ISI quando comparado aos solteiros. Em média, o grupo dos diretores casados tende a diminuir seu ISI em 0,9 (0,908; 0,980 e 0,958, respectivamente nos modelos 1,2,3) em relação aos solteiros. Os demais grupos comparados, a saber: divorciado, viúvo e união estável não apresentaram diferenças significativas em relação aos respondentes solteiros.

A Figura 8 apresenta o ISI Médio dos diretores respondentes por estado civil. Observa-se que os diretores que se declaram casados e viúvos apresentam menor índice comparado com aqueles que declararam outras opções. 
Figura 8 - Índice de Sensibilidade Intercultural médio por Estado Civil na amostra

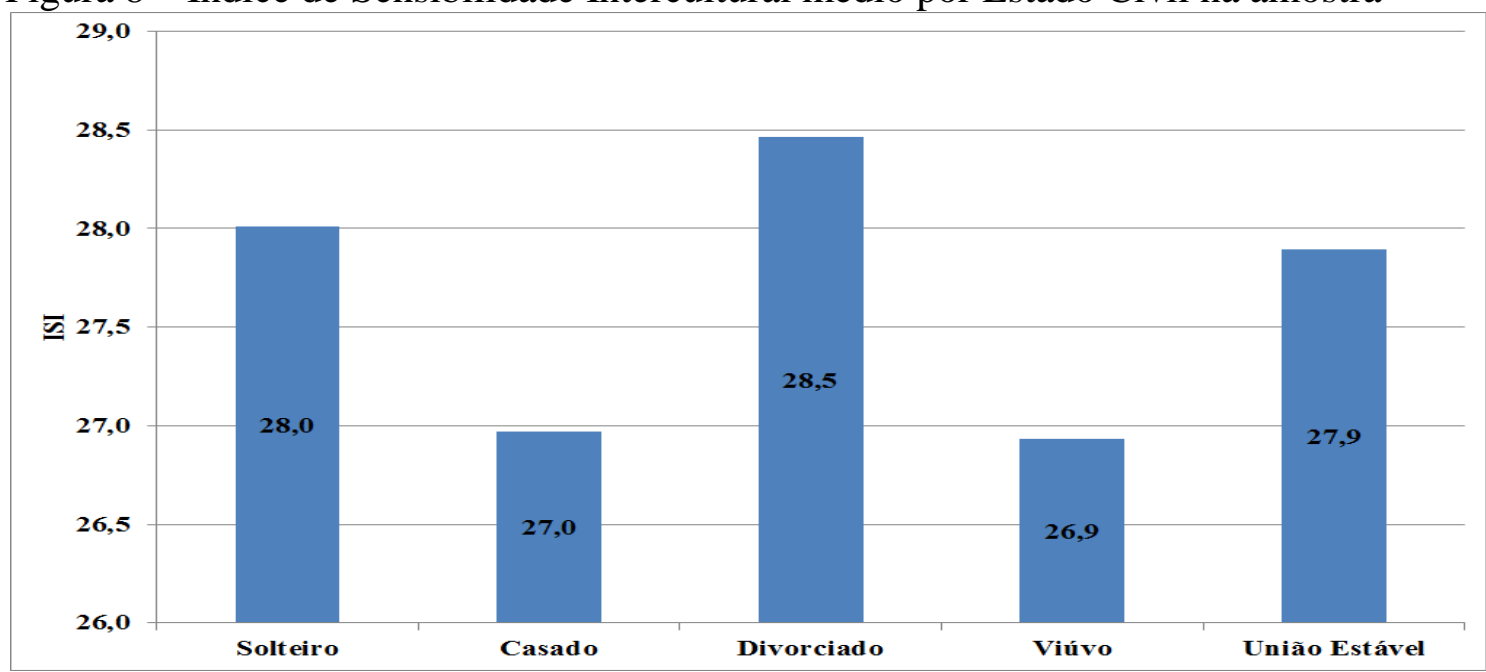

Fonte: Dados da Pesquisa

Observando a figura 4, verifica-se que a diferença entre o ISI de diretores respondentes que se autodeclararam divorciados e dos que se autodeclararam viúvos é de 1,6 pontos. É importante frisar que o grupo de respondentes que optaram por "viúvo" e "união estável" correspondem juntos em torno de $10 \%$ da amostra, totalizando uma pequena fração dos diretores.

No que diz respeito ao grau de escolaridade, infere-se que quanto mais anos de estudo, maior deverá ser o índice de sensibilidade intercultural. A questão pode ser interpretada levando em conta que a quantidade de horas em sala de aula, de certa forma, eleva a empatia das pessoas por culturas distintas. Talvez o conhecimento leve a compreensão do que é distinto de sua própria cultura. Todas as variáveis apresentaram significância estatística ao nível de 1\% em todos os modelos de regressão e a variável de comparação foi "ensino superior".

A Figura 9 apresenta o ISI Médio dos diretores respondentes por grau de escolaridade. Observa-se que os diretores com mestrado e doutorado apresentam maior índice comparado com aqueles que têm as demais formações. 
Figura 9 - Índice de Sensibilidade Intercultural médio por Escolaridade na amostra

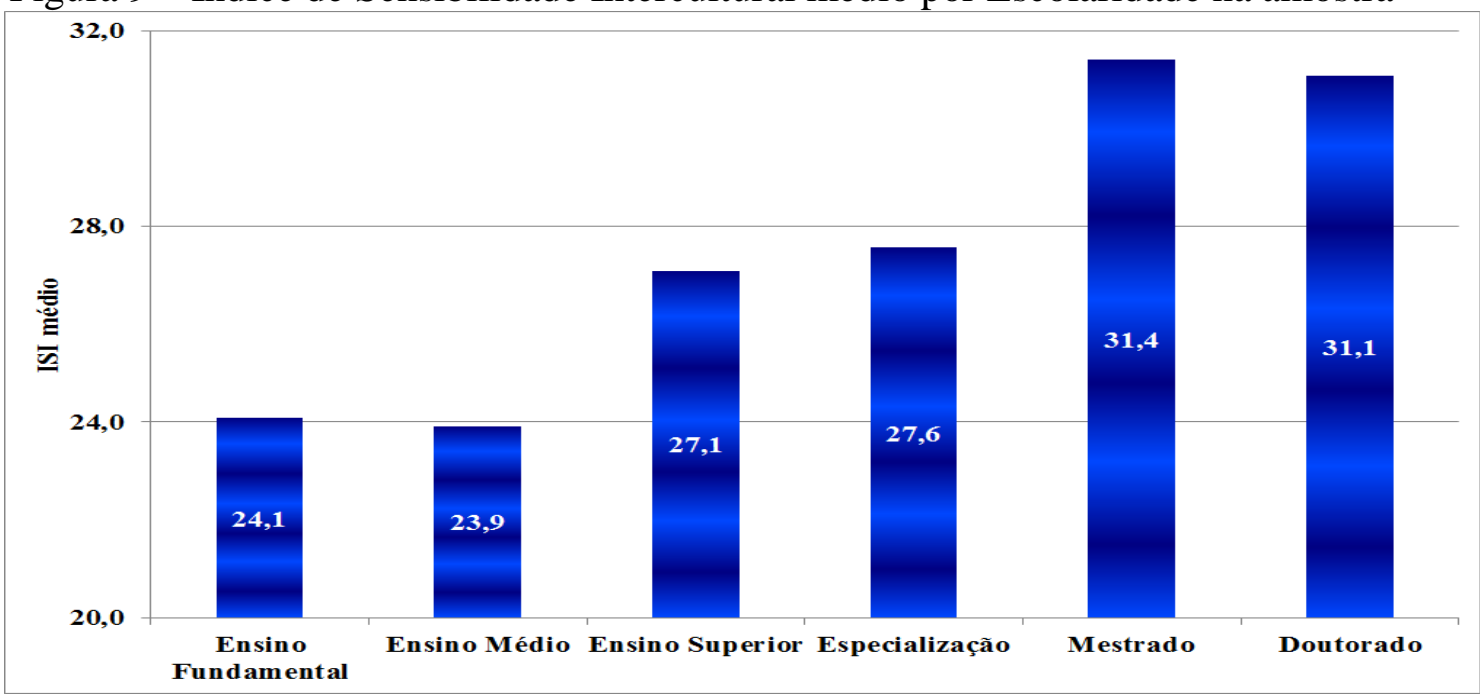

Fonte: Dados da Pesquisa.

Observando a referida figura, verifica-se que a diferença de média entre os mais escolarizados e os menos escolarizados são na ordem de sete pontos a favor dos mais escolarizados. É importante frisar que o grupo de respondentes com ensino fundamental e doutorado representavam uma pequena fração da amostra, talvez por essa razão não apresentarem as menores e maiores médias.

No que diz respeito a variável "Salários Mínimos", os resultados indicam que aumento na quantidade de salários mínimos recebidos pelos respondentes, eleva o ISI em 0,279 pontos em média $(0,273 ; 0,283 ; 0,281$ respectivamente nos modelos 1,2 e 3$)$. A sensibilidade intercultural conceituada por Bennet (1984) é vista como processo de desenvolvimento em que o indivíduo transformar-se afetivamente, cognitivamente e comportamentalmente de estágios etnocêntricos a estágios etnorelativos. $\mathrm{O}$ fato de o indivíduo perceber maior valor financeiro, possivelmente pode dar mais oportunidades para que ele faça essas transformações.

A Figura 10 apresenta o ISI Médio dos respondentes por renda medida em salários mínimos vigentes. É fácil perceber a relação positiva entre as duas variáveis. 
Figura 10 - Índice de Sensibilidade Intercultural médio e a Renda dos diretores de escola

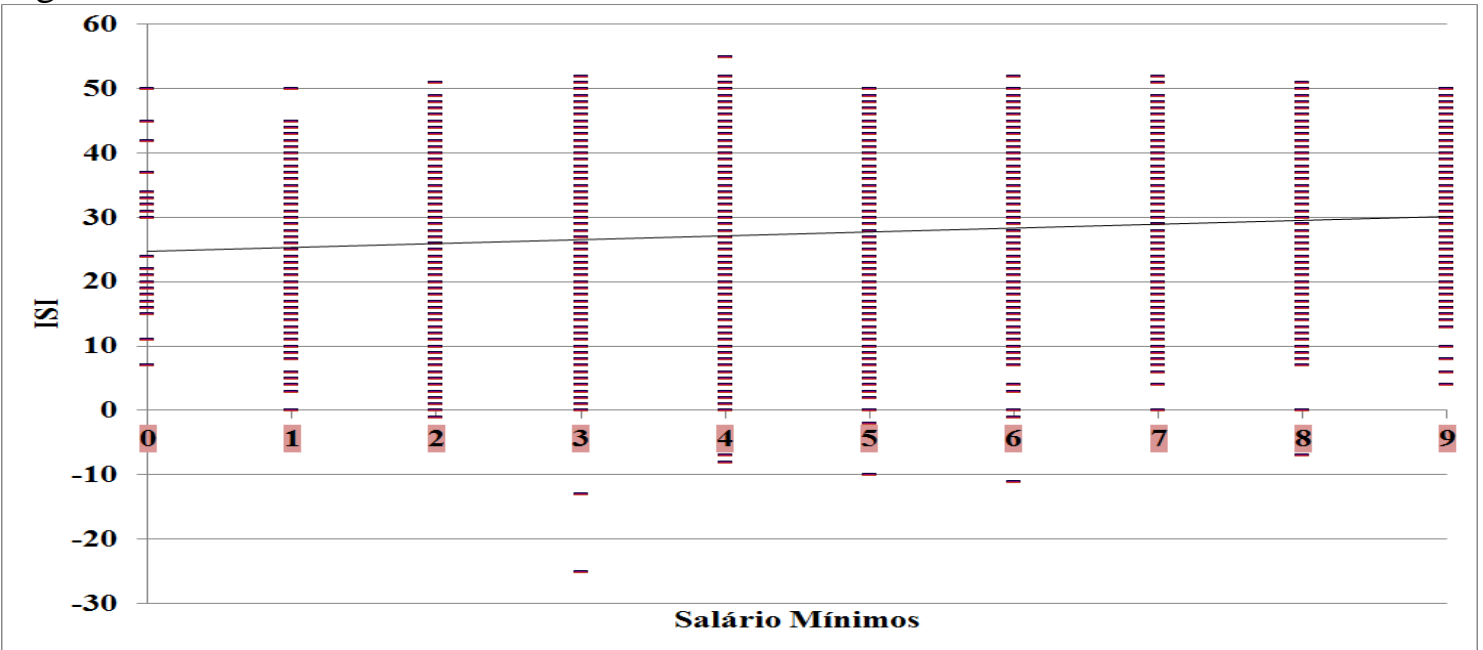

Fonte: Dados da Pesquisa.

A variável "Filhos" apresentou significância estatística nos três modelos de regressão utilizados. Assim, pode-se afirmar que, baseado nesta amostra, quanto maior o número de filhos que o respondente afirmar ter maior será o seu ISI. Em média, cada filho adicional do respondente, o seu ISI médio se eleva em 0,2 pontos. Tal resultado pode ser atribuído ao fato de que ter filhos muda a percepção das pessoas com relação ao mundo, ao fato de filhos deixarem as pessoas mais tolerantes e abertas ao que é distinto de sua cultura.

No que concerne à religião, observa-se que asiática e muçulmana não apresentaram significância estatística. A variável "Protestante" e "Africana" apresenta significância estatística ao nível de 1\%. A variável "Judaica" e "Outras religiões" apresentam significância estatística no nível de 5\%. Os diretores que se autodeclararam protestantes são os que apresentam menor ISI enquanto que aqueles que declaram o judaísmo como sua fé, apresentam o maior. Tal questão talvez encontre explicação na história do povo judeu, marcada por perseguições e extermínios e tais traços históricos expliquem a maior tolerância. Por outro lado, maiorias religiosas pode trazer maior insensibilidade. A Figura 11 apresenta o ISI médio por grupos religiosos. 
Figura 11 - Índice de Sensibilidade Intercultural médio por grupos religiosos na amostra

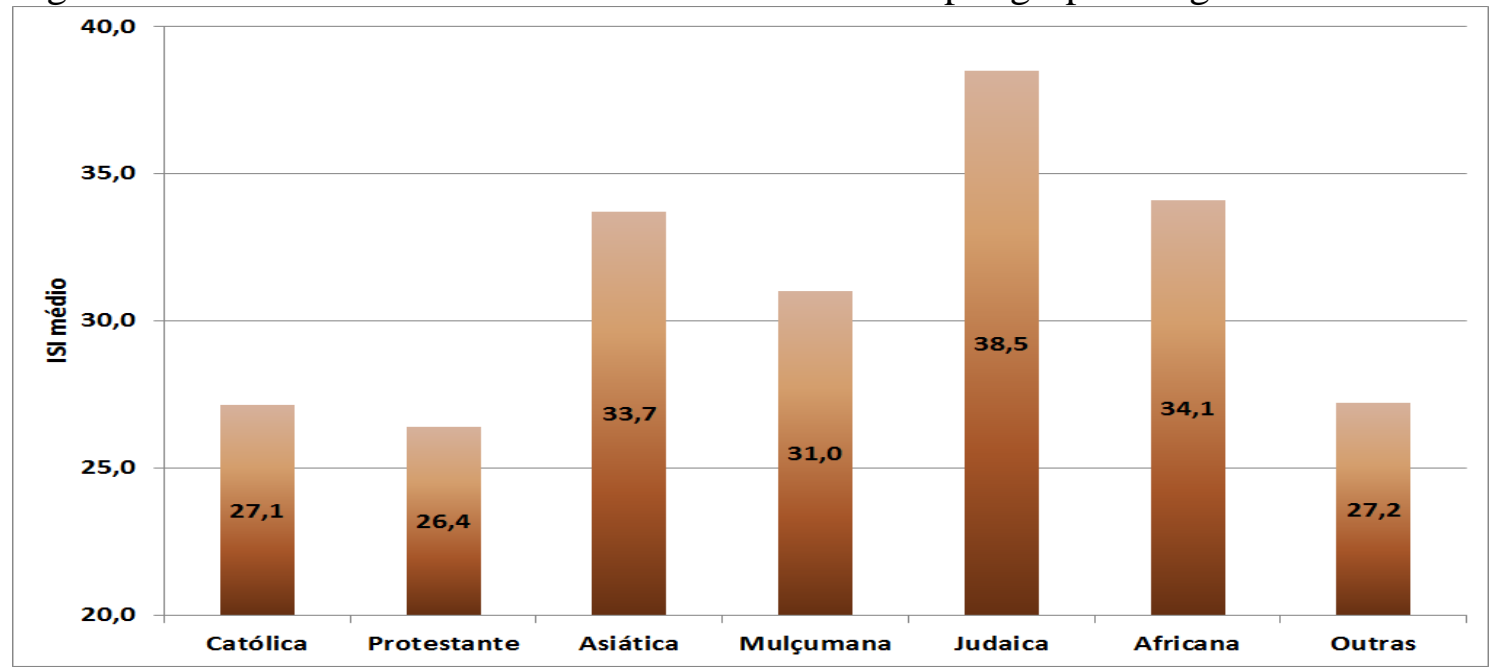

Fonte: Dados da Pesquisa.

Na referida figura, observa-se o menor índice médio no valor de 26,4 pontos, para os diretores praticantes do Protestantismo. Seguidos pelos praticantes do Catolicismo com 27,1 pontos. O maior ISI é de 38,5 pontos para os diretores praticantes do Judaísmo.

Com relação a variável "cor da pele", foram incluídas quatro dummies para buscar evidências se há correlação estas e o ISI, em comparação com os respondentes que se autodeclararam brancos (grupo de comparação). Todas as opções, excetuando a "Negra", não apresentaram nível de significância estatística. Os diretores que se autodeclararam negros tem em média o ISI 1,922 pontos $(1,877 ; 2,006$ e 1,874, respectivamente nos modelos 1,2,3) maior do que os que se autodeclararam brancos. Os dois grupos (diretores respondentes que se autodeclararam brancos e negros) correspondem a $63 \%$ do total, apesar de ser maioria, não retrata a extensa diversidade de cor da pele no país. Portanto, pode-se inferir que, no Brasil, cor da pele não explica a sensibilidade intercultural.

A variável "Televisão" refere-se a horas de TV assistidas por dia. Ela apresentou significância estatística a $1 \%$. Os resultados indicam que quanto mais horas de televisão por dia há uma redução média no ISI $(0,433 ; 0,427$ e 0,433 nos modelos 1,2 e 3 , respectivamente). Tal resultado pode ser compreendido pois a televisão, no Brasil, é um meio de comunicação muito acessível na maior parte do país. Em alguns casos, ela cria modelos socioculturais que acabam virando paradigmas, e este fato pode dificultar a interação intercultural entre indivíduos com culturas distintas. 
No que diz respeito ao tipo de programa assistido, foram criadas seis dummies, a saber: jornalismo, esportivo, novelas, filmes, programas de auditório e outros programas de TV. Os diretores respondentes que assistem a filmes tem em média o ISI 1,00 ponto maior, comparado aos que assistem aos outros itens. Aqueles que assistem novelas tem ISI em média 0,979 pontos menor do que os que optarão por outras programações televisivas.

No que tange a variável "computador", trata-se da quantidade de computadores, desktops, notebooks e tablets na residência do diretor respondente da pesquisa. Esta variável apresentou significância estatística nos 3 modelos apresentados. A cada novo eletrônico, o valor do ISI aumenta em média $0,386(0,387 ; 0,380$ e 0,390 , respectivamente nos modelos 1,2 e 3$)$. Tal resultado pode se dar ao fato de que maior quantidade de computadores, pode gerar maior acesso a informação. E quanto mais informação relativas a outras culturas o indivíduo obtiver, existe a possibilidade de maior empatia cultural e consequentemente maior ISI.

A variável "Internet" refere-se a quantidade de horas por dia que o diretor respondente utiliza esta ferramenta. A cada hora adicional que o diretor passa navegando por dia, o ISI médio aumenta em 0,365 (0,370; 0,362 e 0,364 respectivamente nos modelos 1,2 e 3). Tal fato possivelmente possa ser explicado pelo mesmo motivo do parágrafo anterior. $\mathrm{O}$ maior acesso a informação abre os horizontes pessoais, podendo produzir a mudança afetiva, cognitiva e comportamental necessárias a evolução da sensibilidade intercultural. Essa variável apresentou significância estatística a $1 \%$.

No que diz respeito a viagens ao exterior, os resultados mostram que o fato do diretor respondente ter feito, pelo menos uma viagem ao exterior, eleva o ISI em média em 0,571 pontos. Este fato demonstra que ter contato com culturas distintas, eleva a capacidade de interação intercultural do indivíduo, elevando por consequência o ISI. Essa variável apresentou significância estatística a $1 \%$ nos três modelos apresentados.

$\mathrm{O}$ fato de o diretor respondente da pesquisa ter ou não morado no exterior, interfere no valor de seu índice. A variável residência no exterior apresentou significância estatística a $1 \% \mathrm{em}$ todos os modelos. O ISI tem um aumento médio de 2,784 pontos $(2,823 ; 2,775$ e 2,765 respectivamente nos modelos 1,2 e3) para aqueles diretores que já residiram fora do país. Esta questão pode ser compreendida pois o evento de residir no exterior provavelmente gera forte 
convivência com uma cultura distinta. Isto possivelmente eleva a aceitação de outra cultura podendo chegar até o último estágio do DMIS, a integração.

Com relação a migração entre estados, esta variável não apresentou significância estatística no modelo 1. Apresentou significância estatística a $5 \%$ e a $1 \%$ nos modelos 2 e 3 , respectivamente. Nos modelos em que foi significativa, a mudança de estados gera um aumento médio de 0,797 pontos $(0,681$ e 0,912 respectivamente nos modelos 2 e3) no ISI. Esse fato ocorre possivelmente pois a migração entre estados, gera ao individuo intensa interação com culturas distintas, em diversos aspectos, tais como a fala, hábitos alimentares, musicais, entre outros. Isto provavelmente gera maior sensibilidade intercultural.

O índice de sensibilidade intercultural sofre modificações em decorrência de diversas variáveis apresentadas nos modelos. É importante ressaltar a contribuição da variável grau de escolaridade, o acesso a educação formal, possivelmente torna a pessoa mais sensível a outras culturas. Da forma como está desenhado, as conclusões futuras podem auxiliar na construção de políticas públicas que em última análise, trarão maior qualidade ao ensino brasileiro. 


\section{Considerações Finais}

A inserção em um mundo globalizado exige das pessoas a capacidade de ser sensíveis interculturalmente. O Brasil, devido a grande extensão territorial, tem uma peculiaridade, exige de sua população a convivência entre diversos traços culturais marcantes e distintos entre si. Por esta razão, a característica da sensibilidade intercultural é tão relevante dentro de nosso território. Voltando o olhar aos diretores de escolas públicas, a competência da sensibilidade intercultural, torna-se uma aptidão necessária.

O presente trabalho teve por objetivo mensurar o grau de sensibilidade intercultural dos diretores de escolas públicas no Brasil e buscar evidências sobre quais características individuais, institucionais, socioeconômicos e localizacionais influenciam nesse grau de sensibilidade intercultural. Como objetivos específicos foram a construção e validação de um índice para medir o grau de sensibilidade intercultural, a mensuração do grau de sensibilidade intercultural entre os diretores de escola públicas, o conhecimento do perfil desses diretores em relação à sensibilidade intercultural, a análise da relação entre o índice de sensibilidade intercultural e o perfil dos diretores e por fim, a partir dos resultados encontrados, orientar políticas públicas.

Através dos resultados obtidos na realização da pesquisa, observou se que uma série de variáveis individuais, institucionais, socioeconômicas e localizacionais estão relacionada ao ISI. Com essas evidências, foi possível construir o perfil do diretor que apresenta maior sensibilidade intercultural. A partir dos resultados de regressão, pode-se afirmar que o indivíduo com os maiores ISIs tem o seguinte perfil:

- Está na faixa dos 50 anos de idade;

- Não é casado;

- Tem grau de escolarização de mestrado ou doutorado;

- Possui um maior número de filhos;

- Encontram-se nas maiores faixas de renda salarial;

- Professa religião judaica e africana, ou não é de religião protestante;

- Se autodeclara Negro; 
- Assiste a poucas horas de televisão por dia;

- Quando assiste televisão, prefere filmes e jornalismo e não assiste a novelas;

- Tem computador e outros equipamentos similares em casa e utiliza a internet com regularidade;

- Já viajou ao exterior;

- Já residiu fora do país; e,

- Reside em uma unidade da Federação diferente daquela que nasceu.

Um ensino de qualidade passa por uma boa gestão escolar. O diretor de escola pública, devido a autonomia existente em nossa cadeia de ensino, dá uma direção de para onde a escola deve seguir. A característica da sensibilidade intercultural tratada como desenvolvimento da comunicação entre pessoas, como tecnologia de transporte que liga pessoas de diferentes origens e de diversas regiões, como ferramenta de competição saudável para alunos mais desenvolvidos cognitivamente, como desenvolvimento do multiculturalismo que afeta inúmeras áreas da vida humana deve ser desenvolvida com a devida atenção.

Nesse sentido propõe-se políticas públicas de desenvolvimento da sensibilidade intercultural dos diretores de escolas públicas no país. Essas políticas públicas passam por diversas áreas, muitas delas voltadas ao desenvolvimento sociocultural e individual do diretor. Tais ações devem ser voltadas para estimular o aumento do grau de escolaridade, estimular o intercâmbio, a viagem a outros países, aumentar o alcance e o acesso a internet, criar programas para que os diretores conheçam a cultura e a história de outros estados brasileiros, e se possível os visitem e conheçam as diferentes realidades existentes.

É importante frisar, que o desenvolvimento da sensibilidade intercultural perpassa por situações em que as pessoas interagem com culturas distintas, não há como aprender e interagir com outras culturas, sem ter contato com ela. 


\section{REFERÊNCIAS BIBLIOGRÁFICAS}

AGARWALA A. N. ; SINGH S.P. La economia del subdesarrollo. Madrid: Editorial Tecnos,1963. p.333-374

BARDERN, Sejal M.; SHANNONHOUSE, Laura \& MOBLEY, Keith. International Cultural Immersion: assessing the influence of a group intervention on intercultural sensitivity for counselor trainees. The Journal for Specialists in Group Work, [S.1], 40:1, p. 117-141, DOI: 10.1080/01933922.2014.992505, 2015.

BARTOLOMÉ, Margarita; CABRERA, Flor. Sociedad multicultural y ciudadanía: hacia una sociedad y ciudadanía interculturales. Revista de Educación, [S.1], n. extraordinário, 2003, p. 33-56.

BATESON, Gregory. Mente e natureza: a unidade necessária. Tradução: Claudia Gerpe. Rio de Janeiro: Francisco Alves, 1986.

BELTRÁN, Joaquín. El nou valor de la diferencia. In: Beltrán, J. [et.al.]. Multiculturalisme i educació. Barcelona: UOC, 2002.

BENNETT, Janet M. Becoming interculturally competent. In: WURZEL, J.S. Toward multiculturalism: a reader in multicultural education. Newton, MA: Intercultural Resource Corporation, 2004, p. 9-13.

BENNETT, Janet M. Cultural marginality: identity issues in intercultural training. IN: PAIGE, R. M. Education for the intercultural experience. Yarmouth, ME: Intercultural Press, 1993 ${ }^{\mathrm{a}}, \mathrm{p}$. 109-136.

BENNETT, Janet M. Towards ethnorelativism: a developmental model of intercultural sensitivity. IN: PAIGE, R. Michael. Education for the intercultural experience. Yarmouth, Maine: Intercultural Press, 1993b.

BENNETT, Janet M.; BENNETT, Milton J. Developing intercultural sensitivity: an integrative approach to global and domestic diversity. IN: LANDIS, Dan. ; BENNETT, Janet M..; BENNETT, Milton. Handbook of intercultural training. 3.ed. Thousand Oaks, CA: Sage, p.147-165.

BENNETT, Milton. A developmental approach to training for intercultural sensitivity. International Journal of Intercultural Relations, [S.1.], v.10, n.2, 1986, p. 179-195. 
BLACK, J.; A.; PAEZ, Antonio; SUTHANAYA, Putu A. Sustainable urban transportation: performance indicators and some analytical approaches. Journal of urban planning and development, 2002.

BRITO, Fausto. As migrações internas no Brasil: um ensaio sobre os desafios teóricos recentes. Ensaio revisto e ampliado do texto apresentado no Taller CELADE de Migración Interna, Brasília, 2007. Disponível em:

<http://www.abep.nepo.unicamp.br/docs/anais/outros/6EncNacSobreMigracoes/ST3/FaustoBrito. pdf >. Acesso em 15 fev. 2016.

BRASIL, Ministério da Educação. Instituto Nacional de Estudos e Pesquisas Educacionais.

Sinopse Estatística da Educação Básica/Censo Escolar 2015. Brasília: MEC/INEP, 2015.

BRASIL, Secretaria de Estado de Estado da Educação do Estado doParaná. SOCIOLOGIA ENSINO MÉDIO .Curitiba, 2007. Disponível em: < http://www.educadores.diaadia.pr.gov.br/arquivos/File/livro_didatico/sociologia.pdf $>$. Acesso em: 01.dez.2016.

BUSSAB, W. O.; MORETTIN, P. A. Estatística Básica. São Paulo: 2009.

CARNEIRO, Beatriz H. Que país é este?. São Paulo, Universidade de São Paulo, mimeo, 1994.

CHEN, G. M.;STAROSTA, W. J. A review of the concept of intercultural sensitivity. Human Communication, 1,1-16, 1997.

CHISNALL, Peter M. Pesquisa Mercadológica. São Paulo: Saraiva, 1980.

DAMASCENO, Nagilane Parente.; KHAN, Ahmad Saeed. ; LIMA, Patrícia Verônica Pinheiro Sales. O impacto do Pronaf sobre a sustentabilidade da agricultura familiar, geração de emprego e renda no Estado do Ceará. Rev. Econ. Sociol. Rural [online], Piracicaba, São Paulo, v. 49, n.1, jan./mar., 2011, p. 129-156. Disponível em:

<http://www.scielo.br/pdf/resr/v49n1/a06v49n1.pdf>. Acesso em: 10 fev. 2016.

DELIA, J. G. ; CROCKETT, W. H., ; GONYEA, A. H. Cognitive complexity and the effects of schemas on the learning of social structures. Proceedings of the 78th Annual Convention of the American Psychological Association, 5, 373-374, 1970.

DUARTE JUNIOR, João Francisco. Fundamentos Estéticos da Educação. 10. ed. Campinas,SP: Papirus, 2008.

FALTERI, Paola. Interculturalismo e culturas no Plural. In: FLEURI, Reinaldo Matias (org.). Intercultura e Movimentos Sociais. Florianópolis: Mover, NUP, 1998. p. 33-43. 
FLEURI, R. M. Educação Intercultural no Brasil: a perspectiva epistemológica da complexidade. Revista Brasileira de Estudos Pedagógicos, Brasília, v.80, n.196, 1999, p.277-289.

FLEURI, Reinaldo Matias; GAUTHIER, Jacques; GRANDO, Beleni S. (Orgs.). Uma pesquisa sociopoética: o índio, o negro e o branco no imaginário de pesquisadores da área de educação. Florianópolis: UFSC/NUP/CED, 2001.

GALEFFI, Dante Augusto. Educação estética como atitude sensível transdisciplinar: o aprender a ser o que se é propriamente. Em Aberto, Brasília, v. 21, n. 77, jun. 2007, p. 97-111.

GALEFFI, Dante Augusto. Estética e formação docente: uma compreensão aplicada. Publicado em: 31 jul. 2009. Disponível em: <http://www.rascunhodigital.faced.ufba.br/ver.php?idtexto=201 >. Acesso em: 19 jan.2016.

GARDENSWARTZ, L. ; ROWE, A. Managing diversity: a complete desk reference and training guide. Homewood, IL: Business One Irwin, 1993.

GILLERT, Arne. Conceitos de aprendizagem intercultural. IN: MOCHILA pedagógica sobre aprendizagem intercultural. Bruxelas: Bélgica: Edições do Conselho da Europa, 2001, p. 17-32. (Coleção T-Kit, n. 4). Disponível em: < http://www.internacional.cneescutismo.pt $/$ LinkClick.aspx $?$ fileticket $=$ Ofkfio5wgzw\%3D\&tabid=2361\&mid=4012>. Acesso em: 15 fev. 2016

GODOY, Arida S. Introdução à pesquisa qualitativa e suas possibilidades. In: Revista de Administração de Empresas, v. 35, n.2, Mar / Abr. 1995, p 57 - 63.

GOERTZEL, Ben. Faces of psychological complexity. Publicado em 8 jan. 2004. Disponível em: <http://www.goertzel.org/papers/intro.html>. Acesso em: 10 fev. 2016.

GUJARATI, D. N. Econometria básica. Rio de Janeiro: Elsevier, 2006.

HAMMER, M. R. A measure of intercultural sensitivity: the intercultural development inventory. IN: FOWLER, S. M.; MUMFORD, M.G. The intercultural source book.Yarmouth, ME: Intercultural Press: 1999b. p. 61-72. v.2.

HAMMER, M. R. Cross-cultural training: the research connection. IN: FOWLER, S. M.; MUMFORD, M.G. The intercultural source book.Yarmouth, ME: Intercultural Press: 1999a. p. 1-18. v.2.

HAMMER, M. R.; BENNETT, M. J.; WISEMAN, R. (2003). Measuring intercultural sensitivity: The Intercultural Development Inventory. In: PAIGE, R. M. Special issue on the Intercultural Development. International Journal of Intercultural Relations, 27(4), p.421-443, 2003. 
KINNEAR, Thomas C., TAYLOR, James R. Marketing Research : an applied approach. 4 ed. New York: McGraw-Hill, 1991, 856p.

KIRCHOF, E. R. Estética e Semiótica de Baumgarten e Kant a Umberto Eco. Porto Alegre: EDIPUCRS, 2003.

LABAT, Claudine; VERMES, Geneviève (Eds.). Cultures ouvertes : sociétés interculturelles. Paris: L’Harmattan, 1994.

LAVALLEE, M.; OUELLET, F.; LAROSE, F. (Eds.). Identité, culture et changement social. Paris: L’Harmattan, 1991.

LOEVINGER. J. Scientific ways in the study of ego development. Worchester, MA: Clark University Press, 1979.

LOEVINGER. J.; WESSLER, R. Measuring ego development. San Francisco, CA: JosseyBass, 1970.

MONTGOMERY, D. C.; PECK, E. A.; VINING, G. G. Introduction to Linear Regression Analysis. 3. ed. [S.1.]: Wiley-Interscience, 2001. 641 p.

MONTGOMERY, D. C.; RUNGER, G. C. Estatística Aplicada e Probabilidade para Engenheiros. 2. ed. Rio de Janeiro: Editora LTC, 2003. 463 p.

MORENO, Isidoro. Derechos humanos, ciudadanía e interculturalidad. IN: MARTÍN DÍAZ, Emma ; OBRA SIERRA, Sebastián de la. Repensando la ciudadanía. Fundación el Monte. Universidade de Sevilla, 1999, p. 9-35.

NAGHETTINI, M.; PINTO, É. J. de A. Correlação e regressão. In: NAGHETTINI, M.; PINTO, É.J. de A. Hidrologia estatística. Belo Horizonte: CPRM, 2007b. cap. 9, p. 355-400. Disponível em: <http://www.cprm.gov.br/publique/media/livro_hidro_estatistica.zip>. Acesso em: 3 dez. 2016.

NANNI, Antonio. L'educazione interculturale oggi in Italia. Brescia: EMI, 1998.

NETER, J.; KUTNER, M.; NACHTSHEIM, C.; LI, W. Applied Linear Statistical Models. 5. ed. New York: Mc Graw-Hill/Irwin, 2004. 1396 p.

OSTROWER, Fayga. A sensibilidade do intelecto. Rio de Janeiro: Elsevier, 1998.

OSTROWER, Fayga. Criatividade e processos criativos. 11.ed. Petrópolis: Vozes, 1996. 
OSTROWER, Fayga. Universo da Arte. Rio de Janeiro: Campus, 1986.

PARASURAMAN, A. Marketing research. Reading, Mass: Addison-Wesley, 1986, 831p. , Marketing research, 2 ed. Reading, Mass: Addison-Wesley, 1991, 898p.

RIBEIRO, D. O povo brasileiro: a formação e o sentido do Brasil. São Paulo: Companhia das Letras, 1995.

RIOS, Terezinha Azeredo. Compreender e Ensinar: por uma docência da melhor qualidade. São Paulo: Cortez Editora, 2003.

SCHERER-WARREN, Ilse. Movimentos sociais e a dimensão intercultural. In: FLEURI, R. M. (Org.). Intercultura e movimentos sociais. Florianópolis: Mover/NUP, 1998, p. 31-32.

SCHILLER, Friedrich. A educação estética do homem. 4. ed. Tradução: Roberto Schwarze Márcio Suzuki. São Paulo: Iluminuras, 2002.

SILVEIRA, Eluza. A dimensão estética no ensino de língua portuguesa: os dizeres de professores em formação na FUNDARTE/UERGS. 2008. [Dissertação de Mestrado]. São Leopoldo, RS, 2008. Disponível em:

<http://www.repositorio.jesuita.org.br/handle/UNISINOS/1950>. Acesso em: 24.jan.2016.

ROMERO, Silvio. Provocações e debates. Rio de Janeiro, Imprensa Nacional, 1910.

(1953), História da literatura brasileira. $5^{\circ}$ edição, 1888. 52 edição, Rio de Janeiro, José Olympio.

Sociologia / vários autores. - Curitiba: SEED-PR, 2006. - 266 p.

TODARO, Michael. A migração da mão de obra e o desemprego urbano em países subdesenvolvidos. IN: MOURA, Hélio (coord.). Migração Interna. Textos Selecionados. Fortaleza, Banco do Nordeste, 1980. Tomo I.

VAINER, C. ; BRITO, F. A migração e seu papel na configuração do território nacional. 24th General Population Conference of the International Union for the Scientific Study of Population (IUSSP), Salvador, Bahia, Brazil, setembro, 2001, p. 18-24.

VAINER, Carlos B. Reflexões sobre o poder de mobilizar e imobilizar na contemporaneidade. IN: POVOA NETO, H. E ; FERREIRA, A.P. Cruzando fronteiras disciplinares: um panorama dos estudos migratórios. [Rio de Janeiro]: Editora Revan/ FAPERJ, 2005. 
VELASCO, Francisco Javier. Desarrollo de la competencia intercultural en alumnado universitario: una propuesta formativa para la gestion en empresas multiculturales. Universitat de Barcelona - Facultat De Pedagogia [Tesis Doctoral], 2004.

WEISBERG, S. Applied Linear Regression. 3. ed. New York: John Wiley \& Sons, 2005. 310 p.

ZABALZA, M.A. El trabajo escolar en un contexto multicultural. Educación multicultural e intercultural. Granada: Impresur, 1992.

ZABALZA, Miguel Angel. Implicaciones curriculares de la educación intercultural. X Congreso Nacional de Pedagogía. Salamanca: Diputación Provincial, 1992.

ZELINSKY, W. The hypothesis of the mobility transition. Geographical Review, 61,219249. 1971 


\section{APÊNDICES}

Apêndice A - Questionário de Pesquisa

Questionário de Pesquisa

Você está convidado a responder este questionário individual e anônimo que faz parte da coleta de dados da pesquisa Sensibilidade Intercultural dos diretores de escolas públicas no Brasil. As respostas comporão um bloco de dados a ser utilizado na pesquisa. Sua colaboração é de extrema importância para construção dessa pesquisa. As informações prestadas são sigilosas e não é necessária sua identificação.

Alguns conceitos importantes para maior clareza ao responder o questionário:

- Cultura é aquele todo complexo que inclui o conhecimento, as crenças, a arte, a moral, a lei, os costumes e todos os outros hábitos e aptidões adquiridos pelo homem como membro da sociedade. As distinções dentro deste complexo são as diferenças culturais.

- A Sensibilidade Intercultural está relacionada a aspectos comportamentais em situações de interação entre indivíduos de culturas diferentes.

Pesquisa: Sensibilidade Intercultural dos diretores de escolas públicas

Pesquisadora: Rayane de Oliveira

Orientador: Luiz Honorato da Silva Júnior

Bloco I - Identificação do perfil demográfico, sociocultural e localizacional do entrevistado.

1. Qual a sua idade?
2. Sexo:
( ) Feminino
( ) Masculino

3. Estado Civil:

( ) Solteiro

( ) Divorciado

( ) União Estável

4. Qual seu nível de escolaridade?

( ) Ensino Fundamental

( ) Ensino Superior

( ) Mestrado
( ) Casado
( ) Viúvo
( ) Outros

5. Qual sua faixa salarial líquida?

( ) Menos do que um salário mínimo

( ) Cerca de um salário mínimo

( ) Ensino Médio

( ) Especialização

( ) Doutorado 
( ) Cerca de 2 salários mínimos

( ) Cerca de 4 salários mínimos

( ) Cerca de 6 salários mínimos

( ) Cerca de 8 salários mínimos
( ) Cerca de 3 salários mínimos

( ) Cerca de 5 salários mínimos

( ) Cerca de 7 salários mínimos

( ) Mais do que 8 salários mínimos

6. Número de filhos:
( ) Nenhum
( ) Um
( ) Dois
( ) Três
( ) Quatro
( ) Cinco
( ) Seis
( ) Mais de Seis

7. Você segue alguma dessas religiões? Qual(is) dela(s)?
( ) Católica Romana
( ) Mulçumana
( ) De origem africana
( ) Nenhuma

( ) Protestante

( ) Judaica

( ) Outras

8. Qual a cor da sua pele, raça ou etnia?

( ) Branca
( ) Amarela (asiática)
( ) Parda

9. Quantidade de horas que você gasta assistindo televisão por dia:
( ) Negra
( ) Raça / Etnia Indígena
( ) Outras
( ) Nenhuma
( ) Menos que uma hora por dia
( ) Cerca de uma e duas horas por dia
( ) Cerca de duas horas por dia
( ) Cerca de quatro horas por dia
( ) Mais de quatro horas por dia

10. Quais tipos de programação você costuma assistir diariamente na TV? (admite respostas múltiplas)
( ) Jornalismo
( ) Programas esportivos
( ) Novelas
( ) Filmes
( ) Programas de auditório
( ) Outros

11. Quantidade de computadores de mesa, notebooks, tablets e smartphones em casa:
( ) Nenhum
( ) Um
( ) Dois
( ) Três
( ) Quatro
( ) Mais de quatro

12. Quantidade de horas que costuma utilizar a Internet por dia:

( ) Nenhuma

( ) Cerca de uma e duas horas por dia
( ) Menos que uma hora por dia

( ) Cerca de duas horas por dia 
13. Quantidade de viagens a outros países:
( ) Nenhuma
( ) Uma
( ) Duas
( ) Três
( ) Quatro
( ) Mais de quatro

14. Você já residiu em outro país?

( ) Sim ( ) Não

15. Marque a sigla de seu estado natal:

$\begin{array}{llll}\text { ( ) } \mathrm{AC} & \text { ( ) } \mathrm{AL} & \text { ( ) } \mathrm{AP} & \text { ( ) } \mathrm{AM} \\ \text { ( ) } \mathrm{BA} & \text { ( ) } \mathrm{CE} & \text { ( ) } \mathrm{DF} & \text { ( ) } \mathrm{ES} \\ \text { ( ) } \mathrm{GO} & \text { ( ) } \mathrm{MA} & \text { ( ) } \mathrm{MT} & \text { ( ) } \mathrm{MS} \\ \text { ( ) } \mathrm{MG} & \text { ( ) } \mathrm{PA} & \text { ( ) } \mathrm{PB} & \text { ( ) } \mathrm{PR} \\ \text { ( ) } \mathrm{PE} & \text { ( ) } \mathrm{PI} & \text { ( ) } \mathrm{RJ} & \text { ( ) } \mathrm{RN} \\ \text { ( ) } \mathrm{RS} & \text { ( ) } \mathrm{RO} & \text { ( ) } \mathrm{RR} & \end{array}$

16. Marque a sigla do estado que mora atualmente:

$\begin{array}{llll}\text { ( ) } \mathrm{AC} & \text { ( ) } \mathrm{AL} & \text { ( ) } \mathrm{AP} & \text { ( ) } \mathrm{AM} \\ \text { ( ) } \mathrm{BA} & \text { ( ) } \mathrm{CE} & \text { ( ) } \mathrm{DF} & \text { ( ) } \mathrm{ES} \\ \text { ( ) } \mathrm{GO} & \text { ( ) } \mathrm{MA} & \text { ( ) } \mathrm{MT} & \text { ( ) } \mathrm{MS} \\ \text { ( ) } \mathrm{MG} & \text { ( ) } \mathrm{PA} & \text { ( ) } \mathrm{PB} & \text { ( ) } \mathrm{PR} \\ \text { ( ) } \mathrm{PE} & \text { ( ) } \mathrm{PI} & \text { ( ) } \mathrm{RJ} & \text { ( ) } \mathrm{RN} \\ \text { ( ) } \mathrm{RS} & \text { ( ) } \mathrm{RO} & \text { ( ) } \mathrm{RR} & \end{array}$

\section{Bloco II - Índice de Sensibilidade Intercultural}

Em seguida você encontrará algumas declarações relativas à sua interação intercultural. Baseado em seu conhecimento e opinião, por favor, indique o seu nível de concordância / discordância com cada uma das seguintes afirmações em uma escala que varia entre "Concordo Fortemente" até "Discordo Fortemente". É importante ressaltar que não há respostas certas ou erradas.

1. Eu gosto de interagir com pessoas de diferentes culturas.

( ) Concordo fortemente ( ) Concordo ( ) Sem opinião ( ) Discordo ( ) Discordo fortemente

2. Tenho a convicção de que consigo interagir bem com pessoas de diferentes culturas.

( ) Concordo fortemente ( ) Concordo ( ) Sem opinião ( ) Discordo ( ) Discordo fortemente 
3. Tenho dificuldades em me comunicar com pessoas de diferentes culturas.

( ) Concordo fortemente ( ) Concordo ( ) Sem opinião ( ) Discordo ( ) Discordo fortemente

4. Posso ser tão sociável quanto eu gostaria quando interajo com pessoas de diferentes culturas.

( ) Concordo fortemente ( ) Concordo ( ) Sem opinião ( ) Discordo ( ) Discordo fortemente

5. Eu respeito os valores de pessoas de diferentes culturas, mesmo que diferentes dos meus.

( ) Concordo fortemente ( ) Concordo ( ) Sem opinião ( ) Discordo ( ) Discordo fortemente

6. Acho que pessoas de outras culturas são inferiores do ponto de vista intelectual e cultural.

( ) Concordo fortemente ( ) Concordo ( ) Sem opinião ( ) Discordo ( ) Discordo fortemente

7. Eu evito formar uma primeira impressão precipitada de indivíduos culturalmente distintos.

( ) Concordo fortemente ( ) Concordo ( ) Sem opinião ( ) Discordo ( ) Discordo fortemente

8. Eu me considero com a mente aberta para interagir com pessoas de diferentes culturas.

( ) Concordo fortemente ( ) Concordo ( ) Sem opinião ( ) Discordo ( ) Discordo fortemente

9. Eu tenho algum constrangimento em interagir com pessoas de diferentes culturas.

( ) Concordo fortemente ( ) Concordo ( ) Sem opinião ( ) Discordo ( ) Discordo fortemente

10. Eu tenho a sensação de ser útil quando interajo com pessoas de diferentes culturas.

( ) Concordo fortemente ( ) Concordo ( ) Sem opinião ( ) Discordo ( ) Discordo fortemente

11. Eu respeito a maneira como as pessoas de diferentes culturas se comportam.

( ) Concordo fortemente ( ) Concordo ( ) Sem opinião ( ) Discordo ( ) Discordo fortemente

12. Causa-me alguma irritação a interação com pessoas de diferentes culturas.

( ) Concordo fortemente ( ) Concordo ( ) Sem opinião ( ) Discordo ( ) Discordo fortemente

13. Interessa-me muito interagir com pessoas de diferentes culturas.

( ) Concordo fortemente ( ) Concordo ( ) Sem opinião ( ) Discordo ( ) Discordo fortemente

14. Eu tenho o interesse em ouvir as opiniões de pessoas de diferentes culturas.

( ) Concordo fortemente ( ) Concordo ( ) Sem opinião ( ) Discordo ( ) Discordo fortemente

15. Causa-me algum desagrado a presença de pessoas de diferentes culturas.

( ) Concordo fortemente ( ) Concordo ( ) Sem opinião ( ) Discordo ( ) Discordo fortemente 
16. Tenho satisfação quando descubro diferenças culturais entre uma pessoa de cultura distinta e a minha.

( ) Concordo fortemente ( ) Concordo ( ) Sem opinião ( ) Discordo ( ) Discordo fortemente

17. Tenho muitos amigos de diferentes regiões.

( ) Concordo fortemente ( ) Concordo ( ) Sem opinião ( ) Discordo ( ) Discordo fortemente

18. Acho que tenho um comportamento de desconfiança quando interajo com pessoas de diferentes culturas.

( ) Concordo fortemente ( ) Concordo ( ) Sem opinião ( ) Discordo ( ) Discordo fortemente

19. Tenho tanto interesse em me aproximar de pessoas culturalmente distintas que durante nossas eventuais interações, atenho-me aos sutis significados de sua fala e comportamento.

( ) Concordo fortemente ( ) Concordo ( ) Sem opinião ( ) Discordo ( ) Discordo fortemente

20. Tenho muita facilidade para lidar com amigos de culturas distintas

( ) Concordo fortemente ( ) Concordo ( ) Sem opinião ( ) Discordo ( ) Discordo fortemente

21. Acho que a minha cultura é melhor do que outras.

( ) Concordo fortemente ( ) Concordo ( ) Sem opinião ( ) Discordo ( ) Discordo fortemente

22. Costumo me relacionar com pessoas de regiões diferentes da minha.

( ) Concordo fortemente ( ) Concordo ( ) Sem opinião ( ) Discordo ( ) Discordo fortemente

23. Quando vivencio conflitos decorrentes de diferenças culturais costumo achar que sempre estou completamente certo e a outra pessoa envolvida no conflito errada.

( ) Concordo fortemente ( ) Concordo ( ) Sem opinião ( ) Discordo ( ) Discordo fortemente

24. Entendo que há motivos para evitar situações em que teria que lidar com pessoas culturalmente distintas.

( ) Concordo fortemente ( ) Concordo ( ) Sem opinião ( ) Discordo ( ) Discordo fortemente

25. O Brasil é extenso, e em seu território há inúmeras maneiras de falar, com sotaques, expressões e gírias e eu gosto de todos os tipos de regionalismos existentes no Brasil.

( ) Concordo fortemente ( ) Concordo ( ) Sem opinião ( ) Discordo ( ) Discordo fortemente

26. Eu percebo que as pessoas próximas a mim gostam de interagir com pessoas de diferentes culturas.

( ) Concordo fortemente ( ) Concordo ( ) Sem opinião ( ) Discordo ( ) Discordo fortemente 
27. Tenho a convicção de que as pessoas, de maneira geral, conseguem interagir bem com pessoas de diferentes culturas.

( ) Concordo fortemente ( ) Concordo ( ) Sem opinião ( ) Discordo ( ) Discordo fortemente

28. Percebo que as pessoas, de maneira geral, têm dificuldades em se comunicar com pessoas de diferentes culturas.

( ) Concordo fortemente ( ) Concordo ( ) Sem opinião ( ) Discordo ( ) Discordo fortemente

29. Percebo que as pessoas podem ser tão sociáveis quanto gostariam quando interagem com pessoas de diferentes culturas.

( ) Concordo fortemente ( ) Concordo ( ) Sem opinião ( ) Discordo ( ) Discordo fortemente

30. Percebo que as pessoas respeitam os valores de pessoas de diferentes culturas, mesmo que diferentes dos seus.

( ) Concordo fortemente ( ) Concordo ( ) Sem opinião ( ) Discordo ( ) Discordo fortemente

Muito obrigado pela sua importante participação! 


\title{
Apêndice B - Modelo de convite da pesquisa
}

\author{
Caro(a), Diretor (a).
}

Você foi convidado a participar de uma pesquisa de nome :

"Sensibilidade Intercultural dos diretores de escolas públicas no Brasil".

Você está convidado a responder este questionário individual e anônimo que faz parte da coleta de dados da pesquisa Sensibilidade Intercultural dos diretores de escolas públicas no Brasil. As respostas comporão um banco de dados a ser utilizado na pesquisa. Sua colaboração é de extrema importância. As informações prestadas são sigilosas e não será permitida a sua identificação. Alguns conceitos importantes para maior clareza ao responder o questionário:

- Cultura é aquele todo complexo que inclui o conhecimento, as crenças, a arte, a moral, a lei, os costumes e todos os outros hábitos e aptidões adquiridos pelo homem como membro da sociedade. As distinções dentro deste complexo são as diferenças culturais.

- A Sensibilidade Intercultural está relacionada a aspectos comportamentais em situações de interação entre indivíduos de culturas diferentes.

Pesquisa: Sensibilidade Intercultural dos diretores de escolas públicas

Pesquisadora: Rayane de Oliveira

Orientador: Luiz Honorato da Silva Júnior

Para participar, por favor, utilize o link abaixo.

Atenciosamente,

Rayane de Oliveira (ㅁayane.oliveira@fnde.gov.br)

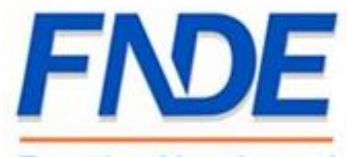

Fundo Nacional de Desenvolvimento da Educação

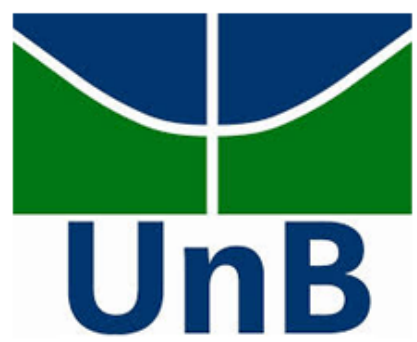

Clique no link para responder o questionário:

http://www.fnde.gov.br/enquete/index.php/survey/index/sid/831378/token/qj42ip6cu7cgbsm/lang/pt-BR

Se você não deseja participar deste questionário e não deseja receber mais convites, por favor clique no seguinte link: http://www.fnde.gov.br/enquete/index.php/optout/tokens/langcode/pt-BR/surveyid/831378/token/qj42ip6cu7cgbsm 
Apêndice $\mathrm{C}$ - Modelo de lembrete da pesquisa

Caro(a), "Diretor",

Recentemente, nós lhe convidamos para participar de uma pesquisa. Notamos que ela ainda não foi finalizada e desejamos lembrar-lhe que o questionário ainda está disponível e que sua participação é de extrema importância. Você faz parte de um todo, e sua participação é fundamental!

Não deixe de responder. Você gastará menos de 10 minutos, o tempo é pouco, mas a contribuição para a pesquisa acadêmica é inéstimável!

Desde já, nossa gratidão!!

O título da pesquisa é:

"Sensibilidade Intercultural dos Diretores de Escolas Públicas no Brasil"

Você está convidado a responder este questionário individual e anônimo que faz parte da coleta de dados da pesquisa Sensibilidade Intercultural dos diretores de escolas públicas no Brasil. As respostas comporão um banco de dados a ser utilizado na pesquisa. Sua colaboração é de extrema importância. As informações prestadas são sigilosas e não será permitida a sua identificação. Alguns conceitos importantes para maior clareza ao responder o questionário:

- Cultura é aquele todo complexo que inclui o conhecimento, as crenças, a arte, a moral, a lei, os costumes e todos os outros hábitos e aptidões adquiridos pelo homem como membro da sociedade. As distinções dentro deste complexo são as diferenças culturais.

- A Sensibilidade Intercultural está relacionada a aspectos comportamentais em situações de interação entre indivíduos de culturas diferentes.

Pesquisa: Sensibilidade Intercultural dos diretores de escolas públicas

Pesquisadora: Rayane de Oliveira

Orientador: Luiz Honorato da Silva Júnior

Para participar, por favor utilize o link abaixo.

Atenciosamente,

Rayane de Oliveira (rayane.oliveira@fnde.gov.br)

Esta pesquisa é fruto de uma parceria entre o FNDE e a Universidade de Brasília - UNB . Participe!

Clique no link para responder o questionário:

http://www.fnde.gov.br/enquete/index.php/survey/index/sid/831378/token/qj42ip6cu7cgbsm/lang/pt-BR 